\title{
Justus Raphelengius (1573-1628) and Turkish folk tales
}

DOI:

10.7817/jameroriesoci.139.2.0333

Link to publication record in Manchester Research Explorer

\section{Citation for published version (APA):}

Palabiyik, N. (2019). Justus Raphelengius (1573-1628) and Turkish folk tales. Journal of the American Oriental Society, 139(2), 333-359. https://doi.org/10.7817/jameroriesoci.139.2.0333

\section{Published in:}

Journal of the American Oriental Society

\section{Citing this paper}

Please note that where the full-text provided on Manchester Research Explorer is the Author Accepted Manuscript or Proof version this may differ from the final Published version. If citing, it is advised that you check and use the publisher's definitive version.

\section{General rights}

Copyright and moral rights for the publications made accessible in the Research Explorer are retained by the authors and/or other copyright owners and it is a condition of accessing publications that users recognise and abide by the legal requirements associated with these rights.

\section{Takedown policy}

If you believe that this document breaches copyright please refer to the University of Manchester's Takedown Procedures [http://man.ac.uk/04Y6Bo] or contact uml.scholarlycommunications@manchester.ac.uk providing relevant details, so we can investigate your claim.

\section{OPEN ACCESS}




\title{
Justus Raphelengius (1573-1628) and Turkish Folk Tales
}

\author{
NiL PALABIYIK \\ LUDWIG-MAXIMILIANS-UNIVERSITÄT, MUNICH
}

\begin{abstract}
Justus Raphelengius, a Leiden printer and orientalist scholar, translated into Latin a sixteenth-century manuscript compilation of Turkish folk tales associated with the famous Anatolian comic figure Nasreddin Hoca. This article considers the role of Raphelengius's translation within the framework of the manuscript circulation and print production of Nasreddin Hoca tales in Europe from the first dated manuscript to twentieth-century printed editions. Raphelengius's editorial choices for his intended publication, the style of his Latin translation, and his excision of bawdy or sacrilegious passages from the original text come under scrutiny.
\end{abstract}

Although it has been established without doubt that the sons of Franciscus Raphelengius (d. 1597), Justus Raphelengius and his brother, also named Franciscus, were both competent Arabists who had undertaken the editing and posthumous publication of their father's Lexicon Arabicum, the first printed Arabic-Latin dictionary in Europe, ${ }^{1}$ Justus's name is rarely, if ever, cited in relation to Turkish studies. His interlinear Latin translation of sixty-seven Turkish folk tales associated with the celebrated jester Nasreddin Hoca, found in Oxford, Bodleian Library, MS Marsh 42, tells a different story. A close look reveals that Raphelengius was an accomplished Turcologist who edited and translated a text riddled with cultural references and idiomatic expressions specific to sixteenth-century central Anatolia. The nearcompleteness of the translation, the selection of tales, and the elegant style of the Latin prose all indicate that he had prepared this manuscript for purposes beyond personal study. Although it never found its way into print, the scholar-publisher Raphelengius clearly wished to make these Turkish folk tales available to learned audiences in early modern Europe in a bilingual edition.

Raphelengius's intended edition of these tales marks a milestone in the publishing history of Nasreddin Hoca stories. His editorial choices and interventions also reveal much about the publishing practices of early modern oriental texts in Europe. In the same way as editors of translations of classics and school texts expurgated and bowdlerized Lucretius or Horace to conform to early modern standards of morality, Raphelengius altered the text he had at hand. ${ }^{2}$ When confronted with profane or bawdy tales, such as one in which an indecent Nasreddin engages in copulation with the Prophet's camel-in fact, he goes so far as to contemplate sexually assaulting the Prophet himself-Raphelengius omitted them from his translation.

I am grateful to the two readers for JAOS, from whose comments this article benefited greatly. I also thank Colin Imber, Christoph K. Neumann, and Clifford Endres for their valuable suggestions, Jan Just Witkam for his generosity in sharing his private notes on Jacobus Golius's manuscripts with me while I was in Leiden as a visiting fellow at the Scaliger Institute in 2015, and The Bodleian Libraries, University of Oxford, for permission to reproduce MS. Marsh 42, fols. 47b, 50a, and 57a.

1. See A. Hamilton," 'Nam tirones sumus': Franciscus Raphelengius' Lexicon Arabico-Latinum (Leiden 1613)," in Ex Officina Plantiniana: Studia in memoriam Christophori Plantini (ca. 1520-1589), ed. M. de Schepper and F. de Nave (Antwerp: Vereeniging der Antwerpsche Bibliophielen, 1989), 557-89, at 579.

2. For case studies of censored Renaissance editions of Lucretius and Horace, see, respectively, D. Butterfield, "Contempta relinquas: Anxiety and Expurgation in the Publication of Lucretius' De rerum natura," and S. Harrison, "Expurgating Horace, 1660-1900," in Expurgating the Classics: Editing Out in Greek and Latin, ed. S. Harrison and C. Stray (London: Bristol Classical Press, 2012), 95-114, 115-27. 
He included some of the lewd tales, yet often resorted to euphemisms in his translation to make them less offensive to his readership.

Nasreddin Hoca, a wise-fool figure and folk philosopher, is perhaps the best-known prankster of the Balkans, Anatolia, and the Middle East. His witty humor and his out-ofthe-ordinary take on daily matters captured the imaginations of people for centuries through anecdotal tales that recount his dealings with townsmen, figures of authority, his congregation, neighbors, and family members. He is often depicted as an imam, an Islamic judge, or a Sufi master, a man of some learning and authority. Yet despite the gravitas that his status accords him, he is excruciatingly inappropriate: he often misbehaves at public gatherings or commits a scandalous act that is guaranteed to raise many eyebrows. He is also intrinsically eccentric, quirky, and witty. Nasreddin is a man who does not conform to the norms of society; rather, he constantly defies the borders of sanity. Sitting backwards on his donkey, he dispenses wisdom of a different order to your usual mullah. He is often blunt, outrageous, cunning, sly, and self-serving, yet it is hard to find fault with his straightforward logic, and even harder to come back with a wittier and more self-righteous punch line than his. The stories are almost always set in a provincial town away from central authority, where Nasreddin seems to have some say in local administration. As such, he often acts as an intermediary for the simpler folk and resolves disputes between inhabitants in his disarmingly practical way.

This article considers the role of Raphelengius's translation within the framework of the manuscript circulation and print production of Nasreddin Hoca tales in Europe from the first dated manuscript to twentieth-century printed editions. Raphelengius's editorial choices, the style of his Latin translation, and his excision of bawdy and sacrilegious passages from the original text all come under scrutiny.

\section{NASREDDIN HOCA IN TURKEY}

The historical figure of Nasreddin Hoca is believed to have been born in the early thirteenth century in Sivrihisar and lived in the town of Akşehir, near Konya in central Anatolia, where one may still find many locals eager to point out his tomb. Nasreddin is a household name in Turkey, where conversations are laced with allusions to his stories and his characteristic punch lines have become proverbs. There is a large corpus of literature on his identity, tales, and legacy in Turkish. ${ }^{3}$ Yet it is impossible to argue with certainty that the Nasreddin Hoca of the tales is the same person as the attested figure of that name. Furthermore, some of the tales attributed to Nasreddin predate the thirteenth century and are, in fact, associated with the Arab jester Juha (Juhāa). ${ }^{4}$ Nasreddin is also known by different names in different regions - for example, Chotzas in Greece, Anastratin in Bulgaria, Mullah in Iran, and Afanti in China. Owing to the ambiguity surrounding the origins of the character and the widespread appreciation of the stories, it is perhaps appropriate to consider him a universal figure of fiction rather than a historical person. The eminent folklorist Pertev Naili Boratav, who spent most of his academic career outside of Turkey as a political exile, refers to multiple Hocas rather than a single factual or fictional character throughout his anthology of Hoca stories.

3. See M. Duman, Nasreddin Hoca kitapları açıklamalı bibliyografyası (1480-2004) (Istanbul: Turkuaz Yayınları, 2004).

4. Ulrich Marzolph discusses the commonalities between Juha and Nasreddin Hoca tales through examples in his Nasreddin Hodscha: 666 wahre Geschichten (Munich: C. H. Beck, 1996), 24-65. See also see U. Marzolph, "Cuha, the Arab Nasreddin in Medieval Arabic Literature," in III. Milletlerarası Türk Folklor Kongresi bildirileri, 5 vols. (Ankara: Ankara Üniversitesi Yayınları, 1986), 3: 251-58. 
The fruit of more than forty years of diligent archival research, Boratav's anthology aimed to build a corpus and to reconstruct the folkloric tradition of Hoca stories from manuscript sources - a textual tradition that had been spoiled by twentieth-century compilations and re-appropriations of Hoca tales that either omitted or "corrected" obscene passages. The anthology was first printed in 1995 by Yapı Kredi Yayınları, a commercial publisher financed by a banking corporation, but was then, ironically, immediately taken out of circulation by the publisher because of the perceived obscenity of some of the tales. A small printrun of the book in its entirety was published a year later by Edebiyatçılar Derneği (The Literary Society), which had limited financial resources. Unlike its predecessors, Boratav's unexpurgated text captured the true spirit of the Anatolian folk tradition and opened a new chapter in Turkish folkloric studies. A second edition of the uncensored anthology appeared in $2006 .{ }^{5}$

The censorship of Nasreddin tales has a long history, beginning with the first printed Istanbul edition of $1253 h$ (1837). This edition carries the unassuming title of Leța' if (Anecdotes); some stories-including the aforementioned tale about Nasreddin's attempted rape of the Prophet's camel, also found in MS Marsh 42_are purged of bawdy jokes and lewd remarks. ${ }^{6}$ Such expurgation, which altered storylines, impaired the natural flow of the text, and left the stories somewhat odd and nonsensical, continued to be employed in later Istanbul prints and the influential Cairo prints of $1254 h$ (1838), 1256h (1840), 1257h (1841), and 1259h (1843). These Bulaq editions became the basis of European translations, and an unbroken line of expurgated Nasreddin Hoca tales thus became cemented in the literary tradition. A number of scholarly and literary anthologies of the stories appeared in Turkey during the Republican era, ${ }^{7}$ yet these were often shaped by their compilers's political views or stylistic concerns. Islamic nationalistic sensitivities mostly prevented the Turkish intelligentsia from appreciating the original Nasreddin tales, although it did not stop them from appreciating equally licentious texts from Renaissance Europe such as Boccaccio's Decameron or Rabelais's Gargantua and Pantagruel. The poet and essayist Enis Batur opined in his preface to the new edition of Boratav's anthology that the opposition Boratav's work received from those who termed the tales "beyond the boundaries of decency" and "inauthentic" was nothing other than turning a blind eye to the element of profanity that was central to the Anatolian oral storytelling tradition. According to Batur, Boratav's opponents found it hard to reconcile this lewd and irreverent character with their ideal of a national hero in what seemed to be an outright rejection of the country's cultural heritage. The religious irreverence permeating the original Nasreddin tales from manuscript sources still remains a topic of fierce dispute in an increasingly Islamicized Turkey. Bowdlerization of the tales was by no means confined to a particular era, locality, or political predisposition. As shall be seen, the obscene nature of some of them troubled editors and publishers of different social, cultural, and political inclinations throughout history, including the translator of the manuscript with which this article is concerned.

5. P. N. Boratav, Nasreddin Hoca (Ankara: Edebiyatçılar Derneği, 1996); idem, Nasreddin Hoca (Istanbul: Kırmızı Yayınları, 2006).

6. Lețâ'if has been made available in a facsimile edition: M. S. Koz, Letâ'if: Nasreddin Hoca fikralarının ilk baskısı. Çeviriyazı-tıpkıbasım (Istanbul: IBB Yayınları, 2008).

7. Some of the important compilations from the period are the historian M. F. Köprülü's Nasreddin Hoca (Istanbul: Kanaat Matbaası, 1918) and the celebrated poet Orhan Veli Kanık's reworked verse edition, Nasreddin Hoca hikâyeleri (Istanbul: Doğan Kardeş Yayınları, 1949). 


\section{NASREDDIN HOCA IN THE WEST}

Nasreddin Hoca is deeply ingrained in the folk culture of the East, but there has also been an abiding interest in his tales in the West. Translations into European vernaculars have long been abundant, and well-known writers quoting Nasreddin without naming him are plenty. Thanks to translations into French (1876), German (1878), and English (1884), there was a vast collection of Nasreddin Hoca tales in print in Western Europe from the nineteenth century onward. ${ }^{8}$ Benjamin Franklin reportedly quoted an anecdote widely attributed to Nasreddin Hoca to illustrate the impossibility of pleasing everyone, ${ }^{9}$ while Goethe, not knowing that a good portion of the tales had been available in Latin since as early as the beginning of the seventeenth century, entertained the idea of his own Latin translation. ${ }^{10}$

The first Nasreddin Hoca manuscripts were brought to Europe in the late sixteenth century. This was no coincidence, since this era saw the emergence in Europe of a burgeoning interest in oriental languages. At the time, there were very few printed resources; orientalists had to procure manuscripts of grammars, dictionaries, phrasebooks, proverb collections, and chrestomathies from the Middle East and North Africa to study Arabic, Turkish, and Persian. Histories, poetry, narrative works, and other types of prose could then be read and understood with the help of these linguistic tools. A good number of manuscripts containing Nasreddin Hoca tales thus found their way into the private collections of learned men. With their repetitive structure, simple plots, and clear style, these Turkish tales make ideal language-learning material.

The earliest dated Nasreddin manuscript brought to Europe is Oxford, Bodleian Library, MS Bodl. Or. 185. This is a codex containing thirty-one folios transmitting forty-three tales associated with Nasreddin (Nașreddīn Hōoca) copied by a certain Husayn on 13 Cumādā el-ūlā 979 (3 October 1571). The Bodleian has several other early modern Hoca manuscripts. The earliest of these is Oxford, Bodleian Library, MS Laud Or. 178, which was bequeathed to the Bodleian Library by Archbishop William Laud (1573-1645) in 1636. ${ }^{11}$ Identical in text, layout, and script with MS Laud Or. 178 is Oxford, Bodleian Library, MS Seld. Superius 8. This codex, which carries the motto of the lawyer and linguistic scholar John Selden (1584-

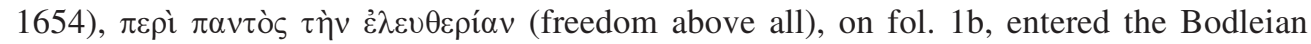
in 1659, when Selden's library was acquired. ${ }^{12}$ The renowned orientalist Edward Pococke (1604-1691) also owned a Nasreddin manuscript, which is now Oxford, Bodleian Library, MS Pococke 26. ${ }^{13}$ Pococke's library was bequeathed to the Bodleian in 1692. None of these

8. Respectively, J.-A. Decourdemanche, tr., Les plaisanteries de Nasr Eddin Hodja traduites du turc (Paris: Ernest Leroux, 1876); F. von Warner, tr., Nasreddin Chodja: Ein osmanischer Eulenspiegel von Murad Efendi (Oldenburg: A. Schwartz, 1878); and G. Borrow, tr., The Turkish Jester, or, The Pleasantries of Cogia Nasreddin Efendi (Ipswich: W. Webber, 1884).

9. H. B. Paksoy, The Bald Boy and the Most Beautiful Girl in the World (Lubbock, TX: ATON, 2003), 8, online at http://vlib.iue.it/carrie/texts/carrie_books/paksoy-8/The_Bald_Boy_Keloglan_and_the_Most_Beautiful_ Girl_in_the_World.pdf.

10. F. Bajraktarevič, "Goethes Interesse für Nasreddin Chodscha," in Jean Deny Armağanı, ed. J. Eckmann, A. S. Levend, and M. Mansuroğlu (Ankara: Türk Tarih Kurumu, 1958), 31-37.

11. Catalogued in E. Ethé, Catalogue of the Persian, Turkish, Hindustani and Pushtu manuscripts, vol. 2: Turkish Manuscripts (Oxford: Clarendon Press, 1889), col. 1186.

12. Ethé, Catalogue, vol. 2, col. 1187. On Selden's library, see G. Toomer, John Selden: A Life in Scholarship, 2 vols. (Oxford: Oxford Univ. Press, 2009), 2: 793; on his interest in Arabic studies, 2: 595-623.

13. Oxford, Bodleian Library, MS Pococke 26, fols. 180a-193b. For a critical edition of the text and a facsimile of the manuscript, see R. Dankoff, "Bodleian kütüphanesinde yeni bulunan bir Nasreddin Hoca yazması," in Uluslararası Türk Dili Kongresi 1992 (Ankara: Ankara Üniversitesi Yayınları, 1996), 123-59. 
manuscripts carries any marginalia by their previous owners, but there are some overlaps between the tales found in Raphelengius's manuscript and the four other manuscripts. Tales 1-3 quoted below, for instance, are also extant in MS Bodl. Or. 185, fols. 13a-14a; and MS Laud Or. 178 and MS Seld. Superius 8, fols. 1b-2a. MS Pococke 26, which lacks the beginning, transmits the last sentence of Tale 2 on fol. 180a. Tale 9, also quoted below, is extant in MS Laud Or. 178 and MS Seld. Superius 8, fol. 3a-b, and MS Pococke 26, fols. 185b-186a. Tale 14, the offensive story about Nasreddin's rape of the Prophet's camel, also appears in Laud Or. 178 and Seld. Superius 8, fol. 8a-b; yet the bawdy Tale 24 seems to be unique to Raphelengius's manuscript MS Marsh Or. 42.14

\section{HOCA MANUSCRIPTS IN EUROPEAN LIBRARIES}

A good number of Hoca manuscripts belonging to different manuscript families can be found in European libraries. Forty-five of these codices have so far been catalogued. The most recent bibliography of Nasreddin Hoca books, Mustafa Duman's Nasreddin Hoca kitaplarl (see n. 3 above), lists forty-one manuscripts housed in European libraries. He is missing three in Manchester, John Rylands Library: (1) Turkish MS 5, a sizable manuscript of 129 folios entitled Menākı b-i Nașreddīn ve gayrihim (Tales of Nasreddin and others), datable to the seventeenth century due to its paper of Venetian origin watermarked with three crescents; ${ }^{15}$ (2) Turkish MS 6, an undated manuscript of forty-eight folios entitled Hikāyāt-ı Hōca Nașreddīn (Hoca Nasreddin Stories); and (3) Turkish MS 7, a manuscript of thirty-two folios entitled Menākı b-ı Hōca Nașreddīn (Tales of Hoca Nasreddin), copied in Șafer 1218 (May-June 1803) and presented to Guillaume-Marie-Anne, Général Brune (1763-1815), the French ambassador to the Sublime Porte at the time, according to the colophon on fol. 32a. All three manuscripts carry the bookplate of the nineteenth-century British orientalist Nathaniel Bland (1803-1865). ${ }^{16}$ Turkish MS 6 has a Latin note by a Renaissance hand in brown ink on fol. $36 \mathrm{~b}$ correcting the spelling of hykrub [sic] that reads " $\dagger$ potius haykirub exclamans" and another note by a different (possibly later) hand in black ink on fol. 43b that reads "faḳi forta[sse] fakīh i[d] e[st] ḥekīm."

Nasreddin Hoca tales were not only actively read by early modern scholars, but also systematically translated. These translations were mainly circulated in manuscript format, but some also saw print. Antoine Galland (1646-1715), better known as the first translator of Thousand and One Nights, perfected his Turkish and cultivated an interest in Ottoman literature and folk tales during his two-year sojourn in Constantinople serving as the translator of the French ambassador to the sultan, Charles-Marie-François Olier de Nointel (1635-1685). ${ }^{17}$ Galland owned a manuscript copied in Constantinople in the first half of the seventeenth

14. For an analysis of the manuscript families and branches of extant Nasreddin Hoca manuscripts, see G. Kut, "Nasreddin Hoca hikayeleri yazmalarının kolları üzerine bir deneme," in IV. Milletlerarası Türk Halk Kültürü Kongresi: Bildirileri, 5 vols. (Ankara: Ankara Üniversitesi Yayınları, 1992), 2: 147-200.

15. On this watermark, see A. Velkov and S. Andreev, Filigranes dans les documents ottomans, vol. 1: Trois croissants (Sofia: Bibliothèque nationale "Cyrille et Methode," Commission archéographique bulgare, section orientale, 1983).

16. These are catalogued in J. Schmidt, Catalogue of the Turkish Manuscripts in the John Rylands Library (Leiden: Brill, 2011), 41-44.

17. On Galland's interest in Turkish folk narratives, see U. Marzolph, "A Scholar in the Making: Antoine Galland's Early Travel Diaries in the Light of Comparative Folk Narrative Research," Middle Eastern Literatures 18.3 (2015): 283-300. 
century containing seventy-one Nasreddin Hoca tales. ${ }^{18}$ He translated and published three of them in 1694, the first known translation of Hoca tales in print. ${ }^{19}$ Moreover, he copied another Nasreddin manuscript of thirty-one folios, possibly for publication at a later date. ${ }^{20}$ More European translations followed that of Galland. We find in Berlin, Staatsbibliothek, MS Orient. quarto 189, an undated early modern manuscript of thirteen folios with an interlinear Italian translation above the Turkish text. ${ }^{21}$ In 1742, Dominique Fornetti, a dragoman working for the French embassy in Constantinople, translated a substantial number of Nasreddin tales into French. His translations are contained in Paris, Bibliothèque nationale, MS Supplement turc 947, a manuscript of thirty-three folios in Turkish copied in European naskh script and sixty-one folios in French. The autograph manuscript carries the title Histoires, contes et fables, traduites du turc en françois par le sieur Dominique Fornetty, jeune de langues de France à Constantinople, $1742 .{ }^{22}$ Fornetti's Turkish text comes from Paris, Bibliothèque nationale, MS Supplement turc 423, a manuscript of thirty-five folios copied by a certain Meḥmed on 17 Żulkạ de 1086 (2 February 1676). ${ }^{23}$ The manuscript was originally found in Akşehir and brought to Constantinople in 1742. Fornetti purchased the manuscript, copied it, translated the tales, and sent both codices to Paris. ${ }^{24}$ MS Supplement turc 423 has an interesting preface penned by its compiler telling the half-mythical story of the composition of the manuscript. Mehmed the scribe introduces Nasreddin Hoca as a historical figure who lived in Akşehir and won the hearts of the locals as their whimsical and eccentric folk hero. According to the scribe, his stories are instructive and humorous. ${ }^{25}$ Readers who have benefited from the morals of these stories should not refrain from saying a prayer for the poor soul who gathered these tales. ${ }^{26}$ Mehmed visits Nasreddin's grave and the same night the jester appears in his dream. ${ }^{27}$ This vision of Nasreddin praying for him and instructing him to write a pamphlet for the public good deeply affects Mehmed, who returns to the grave to say

18. Paris, Bibliothèque Nationale, MS Ancien fonds turc 227.

19. A. Galland, Les paroles remarquables, les bons mots et les maximes des orienteaux (Paris: Simon Benard et Michel Brunet, 1694), 16-18.

20. Paris, Bibliothèque Nationale, Ancien fonds turc 395, entitled Lețā'if-i Nașreddīn Hōca, copied in the hand of Galland.

21. W. Pertsch, Die Handschriftenverzeichnisse der Königlichen Bibliothek zu Berlin, vol. 6: Verzeichniss der türkischen Handschriften (Berlin: A. Asher, 1889), 453.

22. E. Blochet, Catalogue des manuscrits turcs, 2 vols. (Paris: Bibliothèque Nationale, 1932-1933), 2: 105.

23. Blochet, Catalogue, 1: 349 .

24. M. Arslan and B. Paçacioğlu, Letä̀if-i Hō̄ca Naṣreddin (Sivas: [s.n.], 1996), 7.

25. Paris, Bibliothèque nationale, MS Supplement turc 423, fol. 1b, 1. 9- fol. 2a, 1. 3: Ol vakit Hुōca-1 Nașreddīn kim Aḳ şehir I deyü külli ma'rūf nām maḥallda zuhūr edüb, meşhūr-1 I 'āmme-i beni ādem olub, lākin ol caṣrıñ halḳ̂: Nașr- I eddīn Hुōca, bunuñ mürūr ile etdügi kelām-ı dürer bāri I ve bunları imtihānan kāh nașịhat yüzünden ve kāh

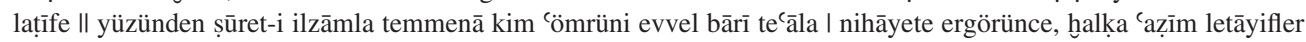
ve garî̉b hikā- I yetler ètmiş idi.

26. Ibid., fol. 2a, 11. 3-12: Ol ḳarındāş kim 'uḳalādan merḥūm I Naṣreddīn Ḥ్̂āceniñ laṭîfelerinden lüṭf-1 hüidāya | maẓhar olub ve ḳıṣsasından hiṣșe almış ola. Anlardan | ricā ve iltimās olunur ki işbu kitābıñ mü̉ellifini hayır | ducā ile añub rūḥuna Fātiḥā-i şerīf oḳuyubl dahıı sevābını bu kitābıñ mușannıfı olub ḩōca ḥażretleri- I niñ lațīfesini cem` edene ị̣sān eyleye ḥaḳk șallā'llāh-u téc̄āă 'aleyhi ve sellem I ile firdevs-i a'lāda ḥaşr eyleye [. . .]

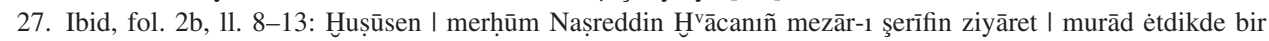
gèce vāḳ amızda görüb bunlardan du$^{\varsigma} \bar{a} \mid$ iltimās ètdikde ayıtdıllar kim bi’emru'llāh te`ālā sizden bize I gelüb du`ā vāṣıl olsa gerek. 
a prayer. ${ }^{28}$ There he meets an old man who is ecstatic with his zeal for Nasreddin. ${ }^{29}$ Mehmed relates his dream, and the wise man interprets Nasreddin's words to mean that Mehmed is tasked with gathering his tales from the oral tradition and putting them into writing as a complete book. ${ }^{30}$ Thus, Mehmed wrote a manuscript in eight parts (sg. $b \bar{a} b$ ) containing 122 Nasreddin Hoca tales (hikēyāt).

A similar preface is extant in Florence, Biblioteca Riccardiana, MS 204, which comprises forty-eight tales on fols. 1a-15a. The manuscript has no colophon, but the 1810 inventory places it in the sixteenth century. ${ }^{31}$ The story with supernatural elements that inspired the production of the Paris manuscript is reproduced in the Florence manuscript (fols. 1b-2b). The pious request inviting readers of the manuscript to pray for Nasreddin and the scribe who copied the tales is also extant.

It is customary in the Islamic manuscript tradition for a copyist of the Quran, a hadith collection, or any other holy text to appeal to readers for their prayers in recognition of the hard labor undertaken in spreading the word of God. Yet, the Hoca tales riddled with blasphemy and profanity clearly do not belong to the religious domain. The prefaces to the Paris and Florence manuscripts may well have served as mock invocations. They are, in a sense, part of the sacrilegious ritual, harbingers of the worldly irreverence to follow.

The manuscript at the core of this article, Oxford, Bodleian Library, MS Marsh 42, has no preface. It comprises sixty-seven Nasreddin Hoca tales in Turkish, written in the central Anatolian dialect. The scribe of the main text identifies himself as a certain Yūsuf Hōca in the colophon on fol. 76a. There is no date, but the codex is datable to the end of the sixteenth and beginning of the seventeenth century by its provenance. Most probably it was purchased in Constantinople by Raphelengius and brought to Leiden, then passed on to Jacobus Golius (1596-1667), professor of Arabic in Leiden, and purchased by Archbishop Narcissus Marsh, book collector and founder of Marsh's Library in Dublin. Marsh secured almost seventy percent of Golius's oriental books and manuscripts (274 items out of a total of 407) at the Leiden sale of $1696 .{ }^{32}$ Marsh's oriental manuscripts were bequeathed to the Bodleian Library in 1714.

The script of the Hoca tales in MS Marsh 42, which measures $8.5 \times 6.5$ inches, is a beautifully formed and vocalized large naksh, lavishly formatted with eleven lines to the page with generous margins. What makes this manuscript unique and interesting is the fact that it was copiously annotated in Latin from beginning to end in the hand of Leiden poet and botanist, Justus Raphelengius (1573-1628), who left his ownership mark at the beginning and the end of the text.

28. Ibid, fol. 2b, 1. 13-fol. 3a, 1. 3: Bendeñiz ayıtdım: "Neden ètdigüm benim senden gāaetde maḥfuz olmuş rumūzum var. II Senden dilerim ki bir risāle èdüb ümmet-i Muhammed içinde sende I şefāêāe maẓhar düşesin.” dedigin gibi uyandım. fi'l-hāl I ravżą -1 Nașreddīn Hōoaya vardum.

29. Ibid., fol. 3a, 11. 3-7: İki rek`at namāz | kıldım selām verdigim gibi șag yanında bir pīr gördüm. I țurmayub

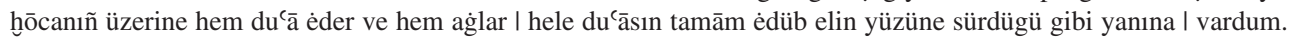

30. Ibid, fol. 3a, 11. 7-12: İşbu gördügüm vāḳı ${ }^{\complement} a-1$ ãña söyledüm. Ayıtdı: "İşbu Hōca I hazretleriniñ lețā’iflerin cēm èdüb bir risāle I etsen gerek ve daḩ ūlū sevāb tạ̣ṣil edüb ve hōọ I hazżretlerine seniñ te’lîf etdigin kitābla ūlūlar hayır du'ā I edüb ve niçe -sevāblar hạaṣıl olacaḳdur.” Ol pīr-i ‘azīz bana I böyle i'lām edüb fỉ'l-hāa gayb oldu.

31. Inventario e stima della Libreria Riccardi: Manoscritti e edizioni del sec. 15 (Firenze: [s.n.], 1810), 9.

32. C. Wakefield, "Arabic Manuscripts in the Bodleian Library: The Seventeenth-Century Collections," in The 'Arabick' Interest of the Natural Philosophers in Seventeenth-Century England, ed. G. A. Russell (Leiden: E. J. Brill, 1994), 128-46, at 136-37. 


\section{JUSTUS RAPHELENGIUS'S TURKISH STUDIES}

Justus is best known as one of the three sons of the celebrated Leiden printer Franciscus Raphelengius, the Elder (d. 1597). Like his father, who compiled the first printed Arabic dictionary, ${ }^{33}$ and his brothers Christoph and Franciscus, Justus was an editor and translator of scholarly texts and an accomplished orientalist. His lasting legacy is the large corpus of printed editions published at Plantin's branch in Leiden, which was run first by his father and then by himself and his brothers. Material on his life is practically nonexistent and research on his contribution to oriental studies is extremely scarce. The two pieces available to me were both written in the previous century and focus solely on Raphelengius's expanded edition (1608) and Latin translation (1618) of Rembert Dodoens's herbal. ${ }^{34}$ A printed primary source is the Leiden auction catalogue of 1626 listing the books owned by Justus, his father, and brothers, ${ }^{35}$ which includes many important Arabic scientific texts printed by Typographia Medicea in Rome, such as the 1593 Avicenna and 1594 Euclid.

Modern scholarship might have dismissed Raphelengius's work as arcane and esoteric, but archival evidence presents him as an accomplished linguist. According to a letter from the classicist Joseph Scaliger (1540-1609) to the physician and Arabist Étienne Hubert (1567-1614), Raphelengius was one of the few orientalists fluent in Turkish at the end of the sixteenth century. Scaliger reported that Raphelengius taught him how the Turks pronounced the word kāfir:

This [word] kâfir, as the circumcised sons of Ismael generally call us, is pronounced really strangely by the Turks, and by writing it, I cannot show [how it is pronounced]. Justus Raphelengius, who studied Turkish in Constantinople, taught me how [to pronounce it]. ${ }^{36}$

Intrigued by this information, Hubert expressed a desire to learn more from Raphelengius and to encourage him to augment Scaliger's work:

You mentioned Justus Raphelengius, and that reminds me to ask what you think about the extent of his knowledge of Turkish. I would make a new kind of wish, if I said I would like him to know Turkish better than me. If this is so, then this is great, and I would miss Hüseyin [the Turkish man who helped Hubert] less. He [Justus Raphelengius] could be approached at one point about the Arabic-Turkish dictionary that you have. ${ }^{37}$

Scaliger must have taken this suggestion to heart; the manuscript of his own Thesaurus Linguae Arabicae features more than one hundred and forty references to Franciscus

33. F. Raphelengius, Lexicon Arabicum (Leiden, 1613).

34. I. Teirlinck, "Joost van Ravelingen - botanist en dichter," Verslagen en mededelingen van de Koninklijke Vlaamse Academie voor Taal- en Letterkunde (1913): 870-92; M. Sabbe, “'Een en ander over Dodoens' Cruydboeck-uitgaven van 1608 en 1618 en de Van Ravelingen's,” De Gulden Passer 15 (1937): 89-106.

35. Catalogus variorum librorum è bibliothecis Francisci Raphelengii (Leiden: Elzevir, 1626).

36. Scaliger to Hubert, 22 March 1608, in The Correspondence of Joseph Justus Scaliger, ed. P. Botley and D. van Miert, 8 vols. (Geneva: Droz, 2012), 7: 464: illud vافر vocare solent recutiti Ismalitae, mire pronunciant Turcae, quo scripto representare non possum; quomodo me docuit Iustus Raphelengius qui Constantinopoli Turcismo operam dedit.

37. Hubert to Scaliger, 8 October 1608, in ibid., 640: Monet me Iusti Rafelengii mentio, a te facta, ut ex te quaeram quid eum Turcice et quatenus scire putes. Novum voti facio cum eum opto esse me doctiorem. Id si est, bene habet, minusque Hussin desidero. Poterit is dictionarium illud Arabico-Turcicum quod apud te est aliqua aggredi. For a full translation and discussion of this letter, see N. Palabiyık, "The Last Letter from Étienne Hubert to Joseph Scaliger: Oriental Languages and Scholarly Collaboration in Seventeenth-Century Europe," Lias: Journal of Early Modern Intellectual Culture and Its Sources 45.1 (2018): 115-46. 
Raphelengius the Elder's Lexicon Arabicum, which was edited and published by Justus and Franciscus the Younger. ${ }^{38}$ Most likely collected during his sojourn in Constantinople, Raphelengius owned quite a few interesting works in Turkish. He read his manuscripts passionately: each includes extensive marginal notes and interlinear annotations in Latin. His manuscript collection, now divided between Leiden University Library and Oxford Bodleian Library, attests to the diversity of his interests and his proficiency in Turkish. He was envied for his competence in Turkish by Scaliger and Hubert, while Golius acquired his manuscripts to aid his own research. In addition to his copy of the Nasreddin Hoca tales, Raphelengius owned and perused a good number of Turkish manuscripts, including the one he termed Oneirokritikon Turcicum, a collection of dream interpretation manuals, ${ }^{39}$ and Mirkāt ul-lug $\bar{a},{ }^{40}$ a sizable Arabic-Turkish dictionary arranged alphabetically according to the first letter, with further thematic groupings. ${ }^{41}$

\section{THE CONTENTS OF OXFORD, BODLEIAN LIBRARY, MS MARSH 42}

MS Marsh 42 is a miscellany of Turkish, Arabic, and Greek texts. The contents are as follows:

1. ff. 1-26, Clavis linguae Arabicae et Persicae (title supplied by Golius), a vocabulary of Arabic words used in conversation and letter writing, arranged alphabetically and explained in Persian [Ethé 1675]. ${ }^{42}$

2. ff. 27-36, Pars Historiae Rousat Sophâ dictae (title supplied by Golius). This is not an excerpt from the fiftenth-century Persian historian Mīr Khwānd's Rawżat al-șafä', but the section on Pythagoras entitled Khabar Fìthāghüras al-faylusūf al-muta'allih from Ibn Abī

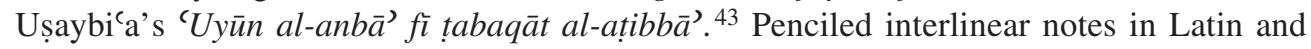
Arabic by Golius. ${ }^{44}$

3. ff. 37-46, De Asiae Desertis (title supplied by Golius), a short, anonymous tract on deserts, in Arabic [Ethé 429].

4. ff. 47-76, Nasreddin Hoca sive Turckschen Eulespiegel (title supplied by Raphelengius), Hikāyāt-ı Nașreddīn Hुōca, sixty-seven short stories attributed to Nașreddin Hōoa, in Turkish with interlinear Latin translation and marginal summaries in Italian [Ethé 2096].

5. ff. 77-92, Compendium Medicinae auth. Rhâzi (title supplied by Golius) contains (1) al-Mudkhal al-saghìr ilā 'ilm al-țibb and (2) Bur' al-sā'a, here given the title Kitāb Dustūr al-tibb fi sirr al-sinā' $a$ wa-bur’ al-sā'a.

38. Hamilton, "Nam tirones sumus," 570.

39. Leiden, University Library, MS Or. 1628; fols. 1a and 92b carry Raphelengius's ownership mark. With marginal notes and Latin transciptions throughout. The manuscript was later acquired by Golius. See J. Schmidt, Catalogue of the Turkish Manuscripts in the Library of Leiden University and Other Collections, 4 vols. (Leiden: Legatum Warnerianum, Leiden University Library, and Brill, 2000-2012), 2: 199-201.

40. This is now Oxford, Bodleian Library, MS Marsh 466. The codex carries Raphelengius's ownership inscription on the unnumbered titlepage. Raphelengius annotated the dictionary in Latin with copious notes on fols. 1-5. Its later owner, Golius, added the Latin equivalents or transcriptions of Turkish words in Latin script on interleaved pages. Two additional leaves with notes in Latin translating the Turkish explications for Arabic headwords, fols. 5-7, possibly in Raphelengius's hand, are folded and glued to the front of the codex.

41. For instance, fols. $8 \mathrm{~b}-9 \mathrm{a}$ are concerned with farm animals. This grouping is further divided into words related to horses (fol. 8b, 11. 7-11) and sheep (fol. 9a, 11. 1-3), etc.

42. Ethé, Catalogue (above n. 11).

43. A. Müller, Ibn Abi Useibia (Königsberg: [Selbstverlag], 1884), 37.

44. This section has Raphelengius's ownership marks both at the beginning and the end. 
6. ff. 93-113, Dictionariolum Arabico-Turcicum (title supplied by Raphelengius), a thematically arranged Arabic wordlist with Turkish equivalents. ${ }^{45}$ Begins with words relating to body parts.

7. ff. 115-121, Zahrabaeûs de ponderibus et mensuris (title supplied by Golius), extract from al-Zahrāwī's Kitāb al-Tașrîf li-man 'ajiza 'an al-ta'lîf, notably the section on weights and measures (tafsīr al-akyāl wa-l-awzān al-mawjūda fì l-kutub al-țibb).

8. ff. 122-139, Doctrina Triliterarum Arab. cum explicatione Anonymi (title supplied by Golius), a short guide to Arabic conjugations presented through ninety possible different forms of the verb $n-s-r$, including verbal nouns and adjectives derived from the same root. Some notes and vowel signs in red ink, possibly by Golius.

9. ff. 140-147, Conjugationes Arabicae cum expositione Turcica (title supplied by Golius), the same work with Italian equivalents and Turkish explication. Notes in Latin, possibly by Raphelengius.

10. ff. 148-160, Claudius Ptolemaeús de astrolabio caeterorumque organorùm (title sup-

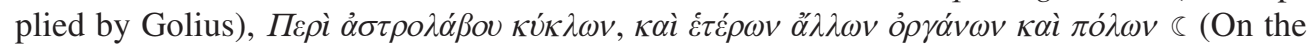
circles of the astrolabe, and other tools and the poles of the moon), a minor work on the astrolabe attributed to Ptolemy. ${ }^{46}$

11. ff. 161-166, Mensurae carminúm omnium Arabicorúm aptatae ad normam Prosodiae Graecae et Latinae inventore et interprete Iacobo Golio, a short work on meter in Arabic and Greek poetry.

Parts 1-3 are copied by Shāhīn b. Qandī al-Ḥalabī ${ }^{47}$ an Armenian Christian who came to Leiden in 1657 and was employed by the university and subsequently by Golius to copy manuscripts. ${ }^{48}$ Part 4 is copied by a certain Yūsuf Hōoca, according to the colophon on folio 76a. Part 6 has no colophon, but the hand is very similar to, if not identical with, that of part 4. Part 7 is copied by Anton Deusing and part 11 is a Golius autograph. ${ }^{49}$

Apart from the interlinear Latin translation, the manuscript contains Raphelengius's Italian marginal summaries of Tales 1-12 (fols. 47b-51b), Latin marginal summaries of Tales 13-16 (fols. 51b-54a), and sparse notes in Italian and Latin next to Tales 17-67 (fols. 54a-76a). Of these, Tales 35, 39, 53, 58, 59, and 61 have fuller marginal notes, whereas 55, 60 , and 67 have none. The notes, scribbled in a smaller script and a darker ink, predate the interlinear translation, as it accommodates the notes and the hand changes direction when obstructed by the marginalia. I have identified Raphelengius's hand after a comparison of characters and letterforms in two autograph letters and an album amicorum entry. ${ }^{50}$ Most

45. This section has Raphelengius's ownership marks both at the beginning and the end. No annotations are extant. The text ends with calligraphy exercises.

46. Also extant in Vatican, Biblioteca Apostolica Vaticana, Pal. gr. 137. See H. M. Stevenson, Codices manuscripti palatini graeci Bibliothecae Vaticanae [. . .] (Rome: Typographia Vaticana, 1885), 66-67.

47. J. Schmidt, "Between the Author and the Library Shelf: The Intriguing Story of Some Middle Eastern Manuscripts Acquired by Public Collections in the Netherlands Prior to 1800," in The Republic of Letters and the Levant, ed. A. Hamilton, M. H. van den Boogert, and B. Westerweel, Leiden: Brill, 2005), 27-51, at 38-40.

48. I identified the hand by comparing it to Manchester, John Rylands Library, Persian 913, fols. 32, 39-40, 45, 93, 134, and 163, already attributed to Qandī in Schmidt, Catalogue [. . . John Rylands Library, 314-30.

49. Anton Deusing (d. 1666) was a student of Golius in Leiden between 1630 and 1637. On Deusing's PersianTurkish-Latin and Turkish-Latin dictionaries newly discovered in Munich, see N. Palabiyı,, "The Unsung Hero of Oriental Studies in Leiden: Anton Deusing and His Turkish Dictionaries," Lias: Journal of Early Modern Intellectual Culture and Its Sources 46.2 (forthcoming 2019).

50. The letters are preserved in Antwerp, Plantin-Moretus Museum Archive, Arch. 92, fols. 237, 243. The album inscription is The Hague, Royal Library, Album Amicorum of Ernst Brinck (1582-1649), envoy and mayor 
distinctive elements of his hand are his two allographs for $e$, one open and one closed, and his single stroke $t$ with a shaft that does not go through the headstroke but only comes out of the right side.

It is notable that Italian explications (in a hand other than Raphelengius's) are also extant in parts 8 and 9 of MS Marsh 42. Italian was the lingua franca in the districts of Galata, the main merchant hub close to the port of Karaköy, and Pera, where most European embassies, including the Dutch resident's quarters, were situated. If Raphelengius had local contacts in Constantinople, whether Turkish, Greek, or Armenian, Muslim, Christian, or Jewish, they would be more likely to speak Italian than any other European vernacular. Most of the correspondence between representatives of the different European powers or communications between the Seraglio and the embassies would be conducted in Italian through dragomans. It was, therefore, perfectly possible to come across secondhand Turkish manuscripts explicated in Italian in the sahafs, the secondhand bookshops, of Constantinople.

Raphelengius provided interlinear Latin translation for the entire Turkish text of part 4, save for a few tales he deemed unworthy of attention. A near-complete translation suggests that Raphelengius intended to publish the tales in print, which he never realized for reasons currently unknown to us. Managing one of Europe's most successful scholarly presses, Raphelengius was also a businessman, and, it seems, his marketing strategy for the printed edition of Nasreddin Hoca's tales was already in place. On the back cover of the manuscript (fol. 76b), he termed Nasreddin Hoca the "Turckschen Eulespiegel," drawing a comparison between the Anatolian mock-hero and the German trickster Till Eulenspiegel. Till Eulenspiegel's stories, laden with impudence and scatological humor, first became available in print in 1510 and were reprinted in $1515 .{ }^{51}$ There are indeed some similarities between the stories featured in the 1515 edition and the sixteenth-century manuscript Raphelengius annotated. By introducing Nasreddin with an allusion to Eulenspiegel, who was decidedly more familiar to a northern European readership, Raphelengius would easily secure a place for his edition in the market for printed books. Furthermore, a bilingual Turkish-Latin edition would be much sought after by scholars who often struggled to find the necessary lexical tools for the study of Turkish.

Although not the only European reader to translate Nasreddin tales into Latin, ${ }^{52}$ Raphelengius is the first identifiable early modern reader to annotate his copy substantially enough to make meaning of his reading. But what exactly did Raphelengius's manuscript contain and what did he make of the text as he read and translated it? The manuscript comprises sixtyseven humorous tales and anecdotes, some witty, some obscene, and some outright crude and bawdy. MS Marsh 42 features a comprehensively diverse selection of tales that exemplifies Nasreddin Hoca's quick-witted, obnoxious, and vile character in all its glory. ${ }^{53}$

of Harderwijk, 133 M 86, fol. 217r. Jan Just Witkam also attributes, albeit tentatively, the hand of the interlinear text to Raphelengius in his notes.

51. Ein kurtzweilig Lesen von Dyl Ulenspiegel (Strassburg: Johannes Grüninger, 1515). The only complete copy survives in the British Library, shelf mark C.57.c.23(1).

52. The only other complete Latin translation that has survived in manuscript known to me is Wrocław, University Library, MS Sygn. M. Or. I 44, a codex of forty-seven folios dated 1808 containing twenty-four tales. See İ. Özkan, “Türkçe ve Latince bir Nasreddin Hoca mecmuası,” Türk Kültürü̈ Araştırmaları 29.1-2 (1991-1993): 272-305.

53. Short summaries of extant tales are given in the appendix below. 


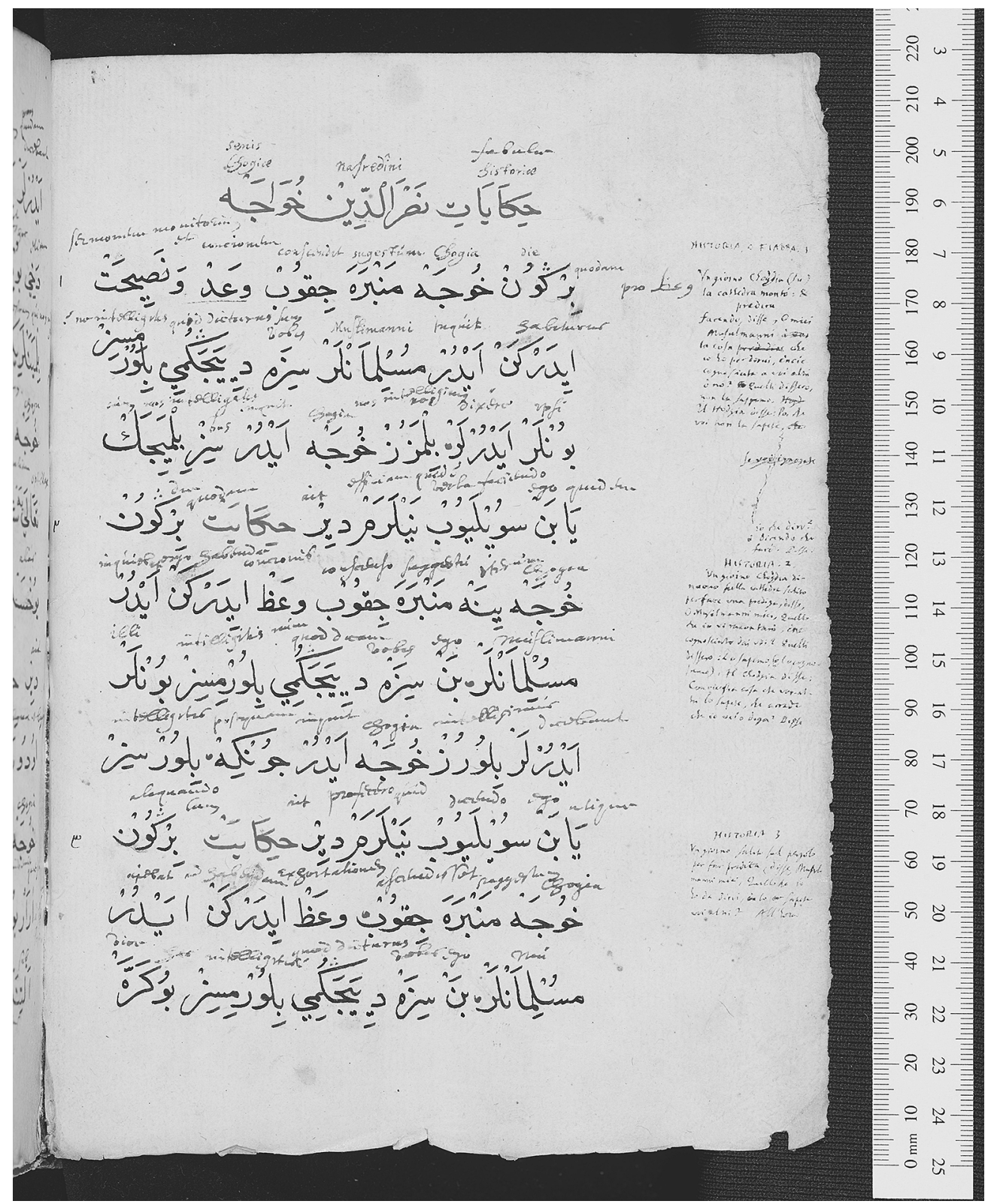

MS. Marsh 42, fol. 47b; courtesy of The Bodleian Libraries, University of Oxford

\section{THE TEXT}

Nasreddin is often termed imām or każı in the extant tales. Yet despite his place in society as an Islamic authority, he shows no respect for religious figures, concepts, or rituals. It is impossible to tell whether Raphelengius found this trope amusing or distressing, but he came to know and appreciate a rarely discussed quality of folk tales from the Islamic world: profanity. Surely, readers found enjoyment in Nasreddin's rigorous but absurd logic; but, 


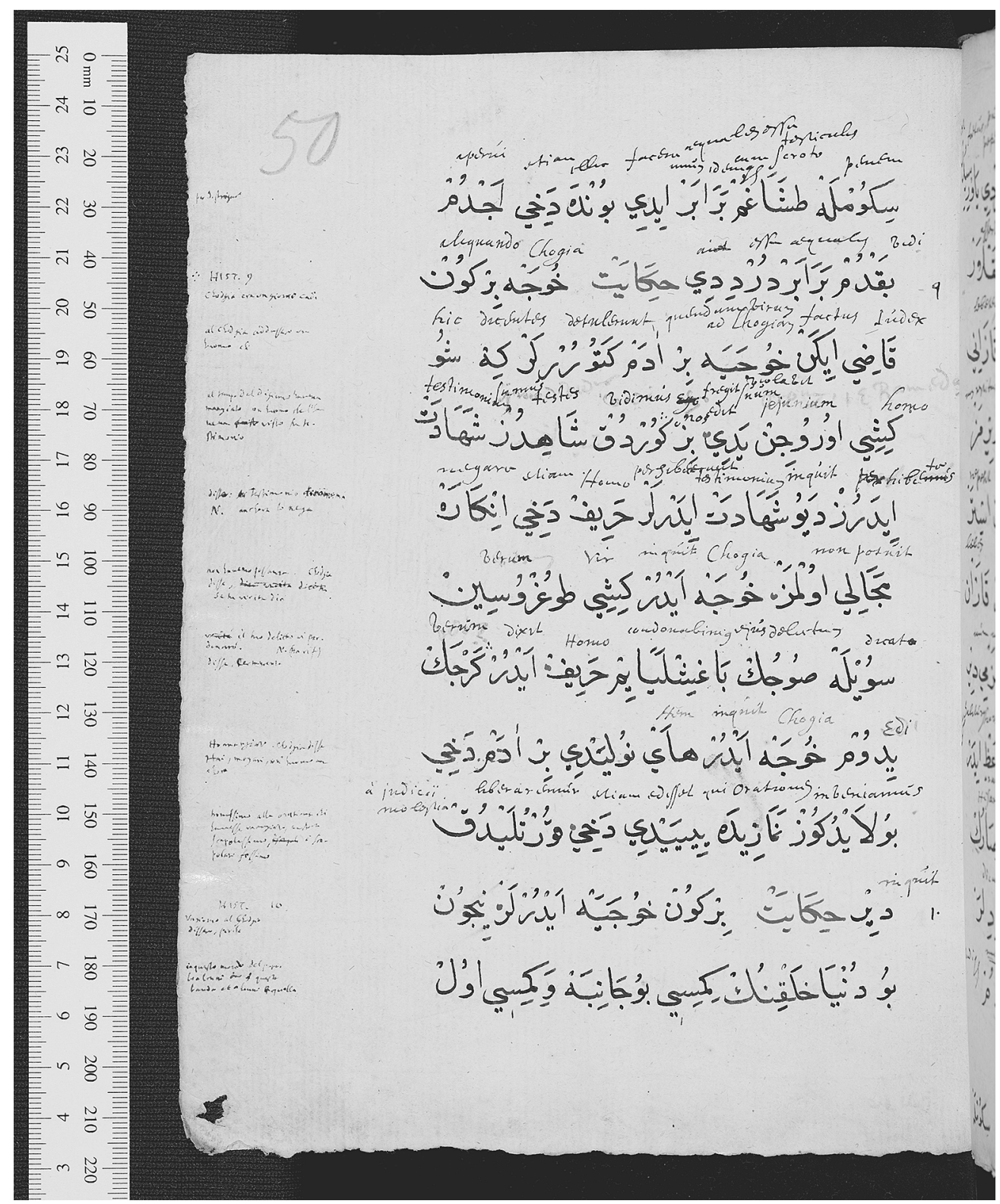

MS. Marsh 42, fol. 50a; courtesy of The Bodleian Libraries, University of Oxford

more importantly, these stories served as an outlet for beliefs and opinions that could not be expressed in public. They provided a safe opportunity to mock religious authority.

The opening sequence of the manuscript consists of three short anecdotes of a repetitive nature, the kind that follows a certain pattern that is comforting and easily recognizable, as, for example, in nursery rhymes or children's stories. These three stories, recounting a lazy Nasreddin's unwillingness to deliver a sermon, are found at the beginning of most manuscripts and printed editions. They are sometimes amalgamated into one longer story and at 


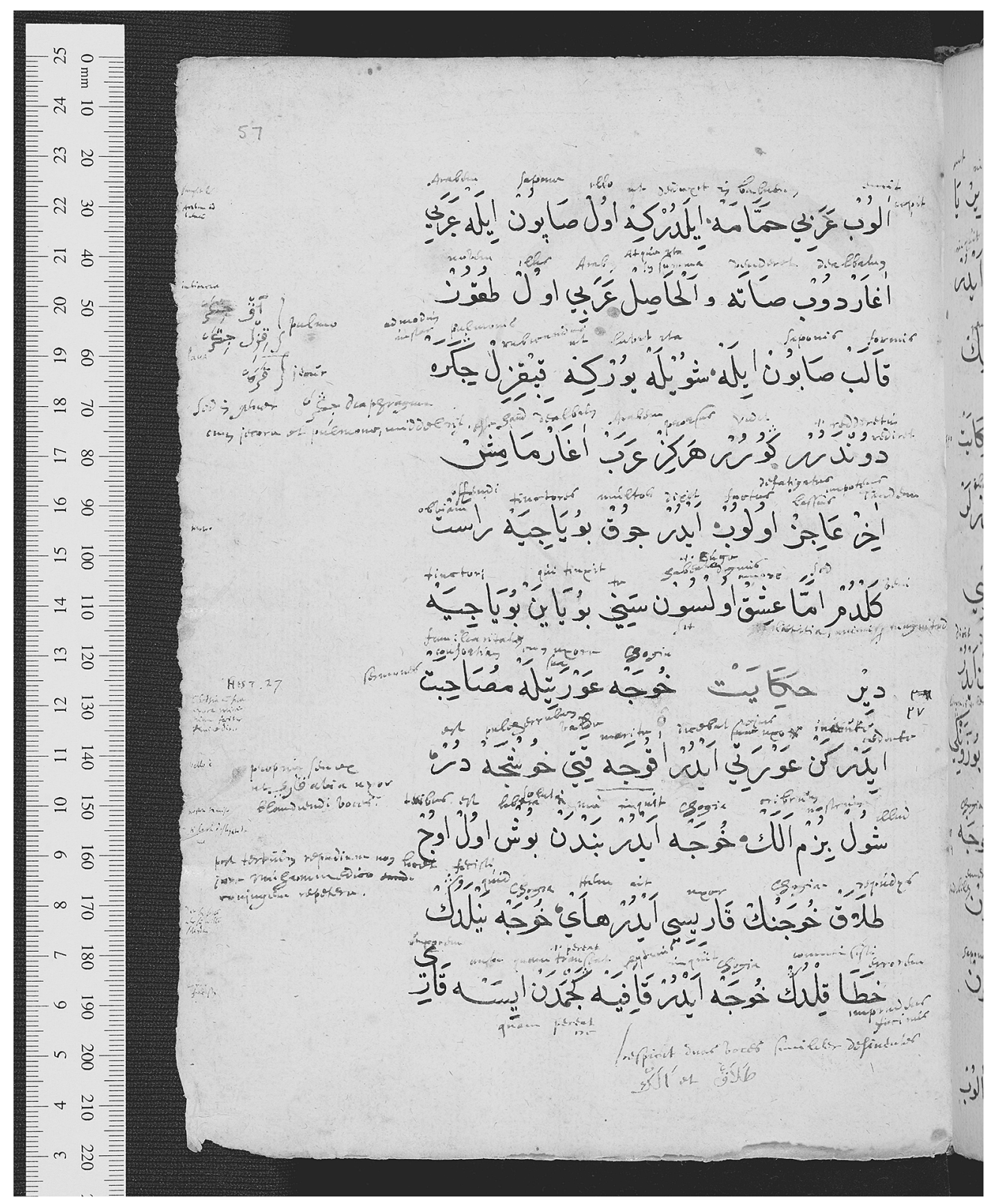

MS. Marsh 42, fol. 57a; courtesy of The Bodleian Libraries, University of Oxford

other times presented separately. ${ }^{54}$ The page layout is as follows, reproducing Raphelengius's marginal notes and interlinear translation: ${ }^{55}$

54. These are numbers 19 to 21 in Günay Kut's system (n. 14 above). See her "Nasreddin Hoca," 159-60. The stories are also extant in the copies owned by Selden and Laud.

55. The following conventions have been employed: <> denotes a deletion by the scribe; [ ] denotes a marginal correction, or one between the lines, added by the scribe; [?] denotes uncertainty on my part with the supplied transliteration. 


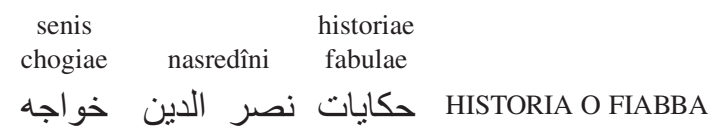

non intellegitis quod dicturus sum vobis Muslimanni inqúit habiturus

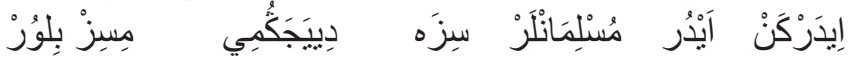

Vn giorno Chògdia (su)

la cattedra montó: \&

predica

facendo, disse, $\mathrm{O}$ miei

Musulmanni

la cosa che

io ho perdovai[?] incio cognosciuta a voi altri o no? quelli dissero,

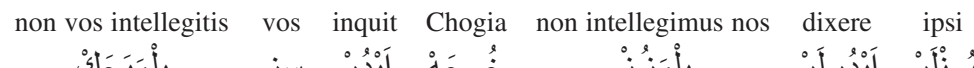

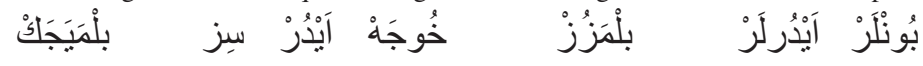

non la sappiamo

Il Hodgia disse: Per che

voi non la sapete,

io che diro?
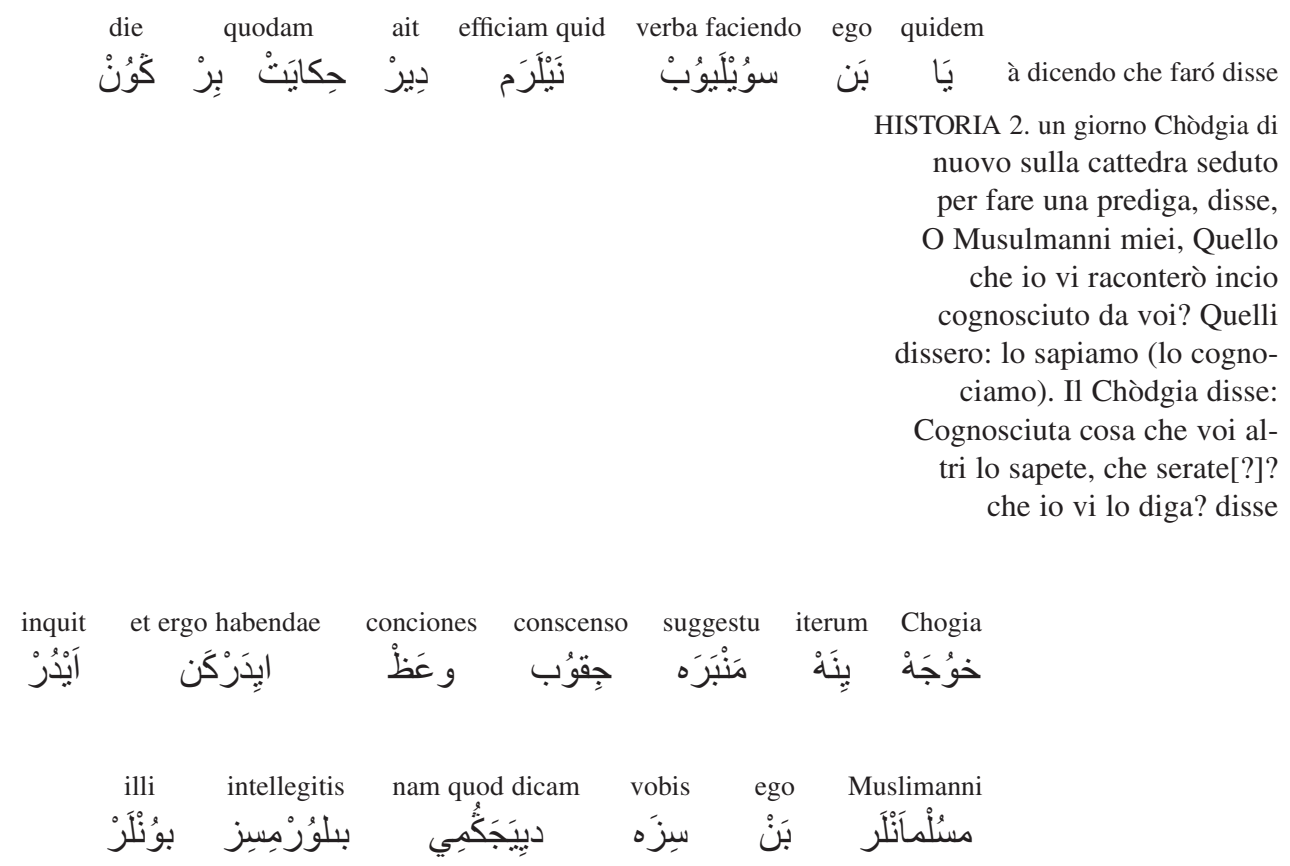


$$
\begin{aligned}
& \text { intellegitis postquam inquit Chogia intelligimus dicebant }
\end{aligned}
$$

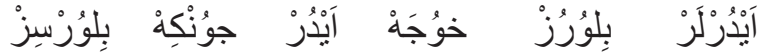

HISTORIA 3

Un giorno salito sul pergolo per far predica, disse: Musulmanni miei, Quello che io ho da dirvi $<$ in $>$ lo $<$.. > sapete voi altri? All'hora

\begin{tabular}{|c|c|c|c|c|}
\hline 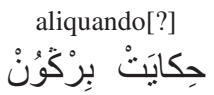 & ديرِّ & $\begin{array}{c}\text { profecero quid } \\
\text { نَبَْرَرَم }\end{array}$ & 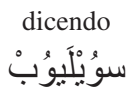 & $\begin{array}{l}\text { ego } \\
\text { بَنْ }\end{array}$ \\
\hline
\end{tabular}

dicebat habendam exhortationem ascendisset suggestum Chogia<smiles>[Al]C1[Si]=[Si]C1[As]</smiles>

vice hac intellegitis quod dicturus vobis ego Mu[slimanni]

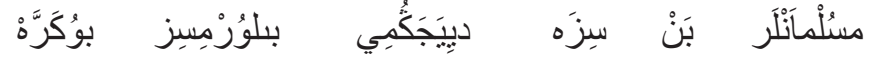

fol. $48 \mathrm{a}$

dissero selettivi di noi lo sanno

$<$ sanno $>$ selettivi di noi non

non[?] lo sanno, diciemo \&

vediamo, che dirà \& sanno

che cosa dissero à noi Chod-

gia disse: Quelli di voi

altri chi lo sanno lo digo

no[?] digano à coloro di voi

chi non lo sanno. Disse

\section{nostrûm}

quidam pars

dicet quid videamus non intelligit pars $<$ non $>$ intelligit nostrûm quidam dicebant

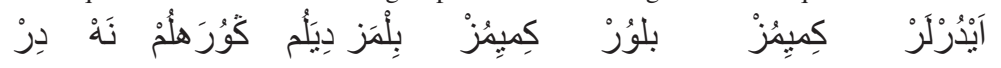

vostrûm qui intelligunt ait Chogia responderunt ipsum hoc etiam

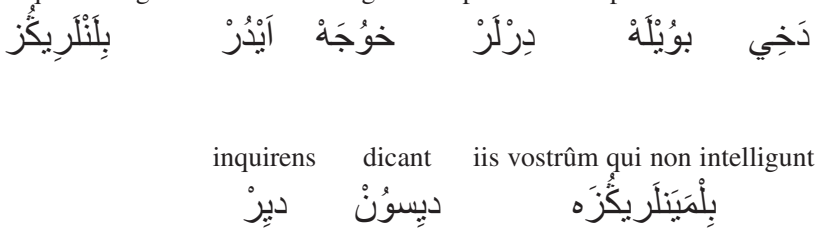

The English translation:

One day Hoca Nasreddin ascends the pulpit to deliver a sermon. He says, "O believers, do you know what I am going to say to you?" The congregation answers, "We do not know." Then Nasreddin replies, "What shall I say to you until you do know?" 
One day Nasreddin, ascending again the pulpit, says, "O devout Muslims, do you know what I am going to say to you?" This time, they reply, "We do know." Then Nasreddin says, "If you know already, what should I have to say to you?"

One day Nasreddin ascends the pulpit, again to deliver a sermon. He says, "O believers, do you know what I am going to say to you?" This time they decide to say that some of them know and some do not. They do so and Nasreddin replies, "Those of you who know should tell it to those who do not."

In the ninth story Nasreddin first commends a member of the congregation for not observing the ritual of fasting, and then expresses his wish that the daily prayers might also be avoided. The story reads, in Raphelengius's translation:

Fol. 50a

Iúdex factus ad Chogiam quendam virum detulerunt dicentes hic

3 każı iken hōocaya bir ādem getirirler ki "Şu violabat

homo jejunium suum fregit nos vidimus testes sumus testimonium edit

4 kişi orucun yedi. Biz görduḳ şahiduz şahādet

ti

perhibe $<$ mu $>$ s inqúit testimonium perhibuerunt Homo etiam negare

5 èderuz" deyu şahādet èderler. Ḥerif daḩı inkāra

non potúit Chogia inqúit Vir verum

6 mecāli olmaz. Hु̄oca eydür: "Kişi toğgrusın

dicate dolatum viris condonabimus Homo dixit verum

7 söyle șucuñ bag̀ışlayayım.” Herif eydür: "Gercek

edi Chogia inqúit

8 yedum." Hōōca eydür: "Hay nolaydı bir ādem dahı

inveniamús qui Orationes edissat etiam liberaremúr à judicii molestia

9 bulaydıñı namāzıda yiyeydi dahı kurtulayduk."

inquiit

10 dèr.

The English translation:

While Nasreddin is serving as a judge they bring him a man. They say, "This man ate while fasting [i.e, broke his fast]. We are witnesses, we can testify." The insolent man does not even care to deny the accusation. Nasreddin Hoca says, "O, my good man, tell the truth and I shall pardon you." The man replies, "I did, indeed, eat." Nasreddin says, "Could you not find another man to consume the daily prayers, so that we can be free of all that, too?" 


\section{RAPHELENGIUS'S LATIN TRANSLATION}

Raphelengius's Latin translation is, for all intents and purposes, a literary one. He clearly wanted to make these stories a pleasurable read for his European edition as he rendered the Turkish eydür (he said) and eydürler (they said) in various forms (e.g., ait, dixit, inquit, respondit, etc.), breaking up the repetitive style that Turkish prefers but Renaissance Latin avoids. He also tried, sometimes in vain, to make the jokes work in translation. In Tale 9, for instance, he suggested three different renderings of the phrase "Şu kişi orucun yedi" (This man broke [ate] his fast): Hic homo suum jejunium fregit / violabat / edit (This man broke / violated / ate his fast). Admittedly, the double entendre is hard to render, especially when one aims for a verbatim translation. Furthermore, Raphelengius misunderstood the joke in the closing sentence. Nasreddin's punch line, "Hay nolaydı bir ādem dahı bulaydıñız namāzıda yiyeydi dahı kurtulayduk," suggests that he wished another man to have eaten the ritual prayer so that they would be absolved of that duty, too. Nasreddin and his congregation would thus be freed from the two most demanding of the five mandatory acts stipulated as the pillars of Islam. But the Latin translation and Raphelengius's marginal explication (à judicii molestia) suggest that if another man to eat the rituals could be found, Nasreddin would be relieved of giving a verdict in this absurd case. The translation may be grammatically correct, but it misses the point.

Raphelengius must have slaved over his text with dictionary at hand, trying to figure out how to translate many tricky Turkish words, including ciger, a noun of Persian origin that means liver, lung, or heart, depending on the context. On fol. 56a, 1. 1, he rendered the word as diaphragma / iecur (midriff / liver) and in the next line he provided the Dutch explication affal (offal), in additon to iecur. On fol. 56a 1. 6, he again writes iecur, but on fol. 57a, 1. 3, a new rendering, pulmo (lung), is introduced. At this point Raphelengius adds a marginal annotation, mixing Latin and Dutch, clarifying his methodology: ak ciger (lung)=pulmo, kara ciger (liver)=iecúr. Sed in gher[?] ciger diaphragma cuius iecoris et pulmones middelrif. Continuing on fol. 57b, 1. 6, he translates ciger as diaphragma and provides the Dutch equivalent middelrif; but on fol. 58a, 1. 1, he only writes diaphragma.

Raphelengius was able to make accurate corrections to the original text, as on fol. 64a, 1. 7, where he corrected the person of the verb conjugation from virmezün (you do not give) to virmezüm (I do not give) and commented: et hoc melius ac usitatius. On fol. 71b, 1. 4, he corrected the vocalization of ölmedin (you did not die) to ölmeden (before dying), and on 1. 9, he corrected the spelling of acar [sic] to açar (opens) - aperit.

He could also make the necessary conjectural emendations where the text was missing, such as on fol. 56b, 1. 6, where he completed a sentence by adding the missing subject (Hōca); and on 1. 7, where he marked a missing sentence with a cross and supplied the absent text in the margin (†Supp[lemen]dae: Eydürler gelündür. [They say this is a bride] Aiunt spousa erat). He even gained a deeper sense of connotations of Turkish words beyond their dictionary definition, as in fol. 53b, 1. 10, where he picked up on the use of libās (dress), commenting Turcae per libās peculiariter intelligúnt vestes meliores. Raphelengius knew that this loan word from Arabic had gained a more specific meaning in Turkish and signified an opulent piece of dress rather than just an everyday garment.

He added marginal explications of difficult grammatical structures, as on fol. 56a, 1. 6, where he underlined alıkor (hinders) and separated the compound verb alıkoymak (to hinder) into its components almak (to take) and komak (to put). He did the same for the compound adverb birazdan (soon), adding in the margin "pro bir et azdan in paulo aliquo." Similarly, on fol. 65a, 1. 8 he underlined the verb işlete (let him/her/it work) and explained in the 
margin that this was the imperative of işletmek (to make sth. work). He clarified puns and explained how they worked in the original text, as on fol. 57a, 1. 11, where he pointed out vocal similarity: "Respirat[?] duas voces similiter desinentes elek et țalāk." He provided explanations for idioms and proverbs as on fol. 59a, 1l. 1-2, where he annotated a Turkish saying. In the corresponding tale, the townsmen steal Nasreddin's cheese and he goes looking for the thieves in the well. When asked why he is looking down the well, he remarks: "Peynir șuyı buldurur" (Cheese takes one to the water) Raphelengius explains this thus: Proverb. nam caseus salsedine súa excitat / sitim: cúi restinguendae / quaeritur aquae potus. Ideo qúo innueret fúres ea de caúsa istúc venturos (Proverb: For cheese provokes thirst through its saltiness. In order to quench it, one seeks to drink water. Therefore, he suggests, the thieves will go there).

While Raphelengius's knowledge of Turkish is impressive, especially given the lack of language learning resources and expertise in the area in this period, his marginal notes and corrections are not free of error. One blunder he repeatedly introduced to the manuscript is his addition of three dots instead of a stroke above the letter known as $g \bar{e} f$ or kāf-ı fārisi. While the Turkish scribe omits the diacritical marks (as is customary), Raphelengius adds three dots, not only correctly when it is pronounced as $\tilde{n}$, but also incorrectly when it is pronounced $g$ or $\breve{g}$ in Ottoman Turkish.

It is possible to infer Raphelengius's stylistic and editorial choices from what he wrote as much as from what he omitted from his Latin text. In places, he abandons his interlinear Latin translation altogether because he finds the story disagreeable or distasteful. The stories he tends to avoid are mostly graphic tales of rape, fornication, and child molestation. This is the case, for instance, from fols. 50a, 1. 10-53b, 1. 4, the section that contains Tales 10 to 15. There is good reason for his discretion. Tale 11 is a story of bestiality in which Nasreddin expresses his admiration for a man who managed to rape a cat while he could never get around to the task. Tale 13 features an indecent Nasreddin who feeds his son yoghurt with his penis. Tale 14 recounts his shocking reaction to being bitten by the Prophet's camel. The story reads:

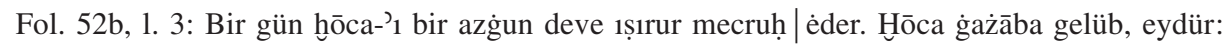
"Gelüñ şu deveyi țutuñ, intikām icün sikeyim dè." Ḩ̄ocaya| eydürler: "Hāy ḩōca utanmaz mısın peyġamberiñ | devesini sikmek istersin?" Hōōa eydür: "Peyġamberüñ | devesin sikmek degül bunda peyġamberiñ 'ammınu|dahı sikerler."

One day a ferocious camel bites Nasreddin and injures him. Nasreddin is furious and says: "Hold that camel and I'll screw it for revenge." They say: "O, Hoca, are you not ashamed to screw the Holy Prophet's camel?" Nasreddin replies: "Ha! The Prophet's camel is nothing, I would even screw the Prophet's cunt."

This was exactly the kind of tale, it seems, that Raphelengius did not want to feature in his edition. Obscenity was an object of considerable anxiety for publishers and educators throughout the Renaissance. While Greek and Latin classics became the basis of school education and enjoyed a wide circulation in print, the texts themselves were subjected to expurgation of lewd passages and vulgar language in order not to harm the morals of young readers. Even learned men such as Raphelengius were inclined to bowdlerization and selective textual excision. There are eleven tales of a sexual nature in the collection. Raphelengius omits only five of them. The other six (including a tale in which Nasreddin tries to engage in an incestuous affair with his sister and another in which he commits adultery) were seemingly more acceptable to Raphelengius's intended readership. Though he translated these 
stories, he made stylistic choices that reflected his taste and disposition. The Latin translation of Tale 24 is a good example of how Raphelengius resorted to euphemisms. Here we find a Hoca who misuses his authority to harass a female peddler, insinuating that she is obliged to do him a sexual favor in order to continue trading at the bazaar. The story reads:

[Fol. 56a]

Quodam die Chogia albúlae

7

Bir gün hōca Aḳca

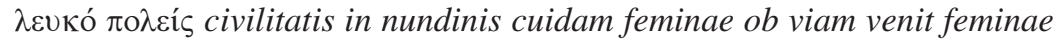
foro

8 şehirün bazarında bir ḳarıya rast gelir. Karıya

ait húc quare venisti et quid negotium túúm est femina

opus

9

eydür: "Bunda neye geldiñ ve ne işiñ $\quad$ vardur?" Karı

10 eydür: "Almā șatmā geldüm." Hōōca eydür: "Ya şimdi her inqúit ad accipiendum mercatandum[?] veni commercandum

Chogia ait at núnc omne vendendum

quod fúerit permitabes tú núm múlier <. . . permitt
11 ne olursa alur șatarmısın?" Avrat: "Aluram șataram."

[Fol. 56b]

inquit Chogia ait vulva ne veneas nón inquiit aut muliebria

1 dèr. Hōōca eydür: "Am șatarmısın?" "Yoḳ” dèr. "Ya

virilia emas non inqúit Chogia inqúit

increpantis Heu vulvulam tuam penis vulva non vendis penis conviviantes

Behey amcıgın sikdügüm, am șatmazsın, sik

non emis at hac quare venisti ait

ob quid

4 șatun almazsın, ya bunda neye geldin? der.

One day Nasreddin comes across a woman in the marketplace of Akçaşehir. He says to the woman, "Why have you come here and what are you doing?" The woman replies, "I have come to buy and sell." Nasreddin says, "So, do you buy and sell anything and everything?" The woman responds, "I do." Nasreddin asks, "Do you sell your cunt?" The woman replies, "No." He asks, "Will you buy my dick?" She says, "No." Nasreddin finally says, "You fucking cunt, you do not sell your cunt, you do not buy my dick, so why are you here at all? 
In all fairness, the Arabic-Turkish wordlist Raphelengius had in his possession (Part 6 of Marsh 42) makes no distinction between the vulgar and the medical use of the words pertaining to the male sexual organs in Turkish in the late sixteenth century. The words sik (penis) and taşāk (testicles) are listed along with other, less graphic body parts in Raphelengius's Arabic-Turkish dictionary on fol. 94b, 1l. 1-8 of the same volume. Even so, it is remarkable that Raphelengius chose to use penis, for instance, and not the more colloquial mentula in his Latin translation. Mentula is a favorite of Catullus, whose poetry was, without doubt, well known to Raphelengius. ${ }^{56}$ Similarly, he preferred testiculi/scrotum over the common colei (balls) on fol. 50a, line $1 .{ }^{57}$ As for the female sexual organ, his Latin translation for am reads vulva and not cunnus. ${ }^{58}$ On fol. 56b, 11.1 and 2, he went one step further and used the euphemisms muliebria (womanhood) and virilia (manhood) to refer to the female and male sexual organs respectively. These editorial choices would seem to clarify that the text was intended to be used as study material rather than as a collection of bawdy tales for light reading.

\section{CONCLUSION}

Raphelengius's intended edition remains the first known Latin translation of Nasreddin Hoca tales. It is remarkable that he devoted extensive time and effort to make these popular Turkish folk stories accessible to a European readership, while, no doubt, improving his own linguistic skills. His intended subtitle "Turckschen Eulespiegel" reveals that it was possible to transfer the folk culture of an entirely different and foreign region to Renaissance Europe by drawing upon similarities and building affinity.

Thanks to humanist scholars' insatiable curiosity and desire to make texts from other periods and civilizations available to readers, by the late sixteenth century northern Europe had reached the intellectual maturity and the cultural openness to reproduce and promote oriental literature. The frightfully apologetic prefaces introducing texts from the Islamic world, with their endless justifications pointing to the perceived merits of these publications-even when they were secular texts such as folk tales, lyric poetry, or grammars-remained a fixed feature of early modern publishing. Yet despite the anxieties their circulation entailed, these texts were printed, distributed, and consumed in large quantities. Had Raphelengius's manuscript seen publication, it would have been very interesting to see what its preface would have looked like. Through ownership marks, entries in sale catalogues, and surviving annotations on printed copies, it would have also revealed who read Turkish folk tales in early modern Europe and what they made of them. More research into Raphelengius's life, especially his sojourn in Constantinople and its aftermath, is needed to determine the timeline and circumstances of his translation effort. His correspondence in Dutch and Latin, which survives intact in the Plantin-Moretus Museum Archives in Antwerp, may still prove a gold mine, as could his other annotated manuscripts. Only a fuller picture of Raphelengius's life and achievements will help us map out his Turkish language learning experience and the cultural ties between early modern European intellectuals and their Ottoman counterparts.

56. See Catullus 29,14; 94,1; 115,8, and others.

57. The word coleus is found in Cicero, Fam. 9, 22,4. In this letter Cicero discusses what makes certain words obscene and asserts his preference for Platonic modesty over Stoic frankness.

58. He did translate ferc as cunnus in his private study notes attached to Marsh 466. Cicero advises against the use of cunnus in Fam. 9, 22,3, while Martial uses the word in abundance. See Mart. 1, 90,7; 3, 72,6; 3, 81,4. 
APPENDIX

\begin{tabular}{|c|c|c|c|}
\hline $\begin{array}{l}\text { Tale } \\
\text { number }\end{array}$ & $\begin{array}{l}\text { Folio and line } \\
\text { number }\end{array}$ & Synopsis & $\begin{array}{l}\text { Interlinear } \\
\text { translation }\end{array}$ \\
\hline 1 & $47 b .2-47 b .5$ & $\begin{array}{l}\text { Nasreddin ascends the pulpit, decides not to deliver his } \\
\text { sermon, because the congregation has no idea what he is } \\
\text { going to say. }\end{array}$ & Yes \\
\hline 2 & 47b.5-47b.10 & $\begin{array}{l}\text { Nasreddin ascends the pulpit, decides not to deliver his } \\
\text { sermon, because the congregation already knows what he is } \\
\text { going to say. }\end{array}$ & Yes \\
\hline 3 & 47b.10-48a.3 & $\begin{array}{l}\text { Nasreddin ascends the pulpit, decides not to deliver his } \\
\text { sermon, because some members of the congregation know } \\
\text { what he is going to say. He suggests that the ones who know } \\
\text { tell those who do not. }\end{array}$ & Yes \\
\hline 4 & 48a.3-48a.7 & $\begin{array}{l}\text { Nasreddin tells the congregation to be grateful to God } \\
\text { because he did not give wings to camels. Otherwise, the } \\
\text { camels would fly and perch on the roofs of their houses, } \\
\text { causing severe damage to the properties. }\end{array}$ & Yes \\
\hline 5 & 48a.7-48b.5 & $\begin{array}{l}\text { Nasreddin comes across a messenger. Not wanting to chat he } \\
\text { pretends to be his donkey's foal. }\end{array}$ & Yes \\
\hline 6 & 48b.5-49a.7 & $\begin{array}{l}\text { Nasreddin borrows his neighbor's donkey. The donkey } \\
\text { drowns in the stream. Nasreddin is brought in front of a } \\
\text { judge. When asked to produce witnesses, he says: "If there } \\
\text { were men around at the time, they would have helped me } \\
\text { save the poor animal." }\end{array}$ & Yes \\
\hline 7 & 49a.7-49b.7 & $\begin{array}{l}\text { Nasreddin borrows a cauldron from his neighbor. He returns } \\
\text { it along with a smaller pot and tells the neighbor that the } \\
\text { cauldron gave birth to the pot. The neighbor is delighted. } \\
\text { He lends his cauldron to Nasreddin on another occasion. } \\
\text { Nasreddin never returns it. When the neigbour demands his } \\
\text { cauldron back, Nasreddin claims that it died. }\end{array}$ & Yes \\
\hline 8 & $49 \mathrm{~b} .8-50 \mathrm{a} .2$ & $\begin{array}{l}\text { Nasreddin claims the weather in Sivrihisar and Akhisar (two } \\
\text { towns in Anatolia) are exactly the same because his testicles } \\
\text { look the same in both places. [explicit] }\end{array}$ & Yes \\
\hline 9 & 50a.2-50a.10 & $\begin{array}{l}\text { A member of the congregation eats [while] fasting; Nasred- } \\
\text { din wishes that he had eaten the ritual prayer as well. }\end{array}$ & Yes \\
\hline 10 & 50a.10-50b.4 & $\begin{array}{l}\text { The townspeople ask Nasreddin why some people walk in } \\
\text { one direction while others walk the other way. Nasreddin } \\
\text { claims the earth would come out of its orbit if all the people } \\
\text { walked in the same direction. }\end{array}$ & No \\
\hline 11 & 50b.4-51a.4 & $\begin{array}{l}\text { While Nasreddin is acting as a judge, they bring in front } \\
\text { of him a man who raped a cat. He demands that the man } \\
\text { tell him the true story and he shall pardon him. The man } \\
\text { describes his vile act in detail. Nasreddin, impressed with } \\
\text { the man's technique, says he tried to rape a cat thirty times; } \\
\text { but each time he ended up with his testicles scratched. } \\
\text { [explicit] }\end{array}$ & No \\
\hline
\end{tabular}




\begin{tabular}{|c|c|c|c|}
\hline 12 & 51a.5-51b.9 & $\begin{array}{l}\text { Two men are brought to Nasreddin's chamber. One claims } \\
\text { that the other bit his ear, while the accused pleads not guilty } \\
\text { and claims that the man bit his own ear. Nasreddin dismisses } \\
\text { both saying he will consider their case. While alone, he tries } \\
\text { biting his own ear; trying really hard he falls off the pulpit } \\
\text { and injures himself. He declares it is impossible to bite one's } \\
\text { own ear without breaking one's skull. }\end{array}$ & No \\
\hline 13 & $51 b .9-52 b .2$ & $\begin{array}{l}\text { Nasreddin's wife goes to the public bath and leaves their son } \\
\text { in Nasreddin's care. The child starts crying, and to comfort } \\
\text { him Nasreddin decides to feed him some yoghurt with his } \\
\text { penis. His wife returns home and is scandalized to see what } \\
\text { Nasreddin is doing. Nasreddin claims that he was right to } \\
\text { feed the child with a soft and safe "utensil" rather than, say, } \\
\text { a sharp metal object such as a knife. [explicit] }\end{array}$ & No \\
\hline 14 & $52 b .2-52 b .9$ & $\begin{array}{l}\text { The Prophet's camel bites and injures Nasreddin. He wants } \\
\text { to rape the animal to take revenge. [explicit] }\end{array}$ & No \\
\hline 15 & 52b.9-53b.4 & $\begin{array}{l}\text { Nasreddin is not willing to fast during Ramadan, but does } \\
\text { not want to miss the feast at the end of the month. So he } \\
\text { puts a stone each day into a bowl to keep tally. His daughter } \\
\text { plays a practical joke on him. }\end{array}$ & No \\
\hline 16 & 53b.4-54a.7 & $\begin{array}{l}\text { Nasreddin is invited to a wedding. He wears old clothes } \\
\text { and nobody pays attention to him. He is invited to another } \\
\text { wedding where he shows up in expensive furs and silks. } \\
\text { This time he is much revered. He offers the food to his gown } \\
\text { saying that the garments deserve the food, not himself. }\end{array}$ & Yes \\
\hline 17 & 54a.7-54b.3 & $\begin{array}{l}\text { Nasreddin comes across half-naked women in a graveyard } \\
\text { grieving for the dead. He wraps his penis with a white } \\
\text { napkin [after the Muslim fashion, who cover their dead in a } \\
\text { shroud] and asks the women if they would also grieve for his } \\
\text { penis. [explicit] }\end{array}$ & No \\
\hline 18 & 54b.3-54b.6 & $\begin{array}{l}\text { As Nasreddin leaves the public bath, a man wishes him } \\
\text { good health. Unable to return the nicety, Nasreddin blabbers } \\
\text { "beribba." }\end{array}$ & Yes \\
\hline 19 & 54b.7-54b.9 & $\begin{array}{l}\text { The townspeople claim that Nasreddin's wife wanders too } \\
\text { much, implying that she sees other men. Nasreddin claims if } \\
\text { she wandered, she would have eventually come to his door, } \\
\text { too. }\end{array}$ & Yes \\
\hline 20 & 54b.9-55a.1 & $\begin{array}{l}\text { One day a thief breaks into Nasreddin's house. He lets the } \\
\text { thief take away whatever he can carry, claiming that what is } \\
\text { left over would be more than what can be taken. }\end{array}$ & Yes \\
\hline 21 & 55a.1-55b.7 & $\begin{array}{l}\text { One day Nasreddin and his wife make plans to go to the } \\
\text { public bath, have a romantic dinner, and make love in the } \\
\text { evening. Their son overhears the conversation and puts a } \\
\text { spanner in the works. }\end{array}$ & Yes \\
\hline 22 & 55b.7-55b.11 & $\begin{array}{l}\text { Nasreddin commits adultery and leaves the explaining to his } \\
\text { penis. [explicit] }\end{array}$ & Yes \\
\hline 23 & 55b.11-56a.7 & $\begin{array}{l}\text { Nasreddin likes eating lamb's liver and claims that it makes } \\
\text { him braver. }\end{array}$ & Yes \\
\hline
\end{tabular}




\begin{tabular}{|c|c|c|c|}
\hline 24 & 56a.7-56b.4 & $\begin{array}{l}\text { Nasreddin asks a woman in the bazaar whether she trades in } \\
\text { pussies and cocks. [explicit] }\end{array}$ & Yes \\
\hline 25 & 56b.4-56b.9 & $\begin{array}{l}\text { Nasreddin goes to a different town to find a bride. Seeing } \\
\text { there are more men than women, he says: "I have never seen } \\
\text { a town with so many pimps." }\end{array}$ & Yes \\
\hline 26 & 56b.9-57a.7 & $\begin{array}{l}\text { Nasreddin buys a black slave just because it is cheaper than } \\
\text { buying a white slave. He takes him to the public bath and } \\
\text { rubs him with soap to "whiten" him. He is disappointed that } \\
\text { the man's "dye" does not wear off. }\end{array}$ & Yes \\
\hline 27 & 57a.7-57b.1 & $\begin{array}{l}\text { Nasreddin says he wants to divorce his wife just to keep the } \\
\text { rhyme with the preceding sentence. }\end{array}$ & Yes \\
\hline 28 & 57b.1-57b.6 & $\begin{array}{l}\text { A woman shows her vagina to Nasreddin and asks him to } \\
\text { take her "casserole" in his hand. Nasreddin takes out his } \\
\text { penis and suggests that he should handle it with his "uten- } \\
\text { sil." [explicit] }\end{array}$ & Yes \\
\hline 29 & 57b.6-58a.3 & $\begin{array}{l}\text { A kite steals the lamb's liver that Nasreddin just bought. He } \\
\text { perches on a high place above the butcher's shop and steals } \\
\text { the next customer's liver, claiming that he is a kite. }\end{array}$ & Yes \\
\hline 30 & 58a.3-58b.9 & $\begin{array}{l}\text { Nasreddin makes a comeback to the sultan, who claims that } \\
\text { Nasreddin is cursed and brings bad luck. }\end{array}$ & Yes \\
\hline 31 & 58b.10-59a.2 & $\begin{array}{l}\text { The townspeople steal Nasreddin's cheese. He goes and } \\
\text { stands next to the public well, claiming that cheese leads one } \\
\text { to the water. }\end{array}$ & Yes \\
\hline 32 & 59a.2-59a.5 & $\begin{array}{l}\text { Nasreddin plants herbs in the morning and pulls them out of } \\
\text { the field in the evening and takes them home. He claims that } \\
\text { he cannot leave his livelihood out there for the taking. }\end{array}$ & Yes \\
\hline 33 & 59a.5-59b.3 & $\begin{array}{l}\text { The townspeople are observing the new moon to determine } \\
\text { how many days are left until the end of Ramadan. Nasreddin } \\
\text { is astonished, saying that even the full moon is not revered } \\
\text { that much in his home town, let alone this excuse of a moon. }\end{array}$ & Yes \\
\hline 34 & 59b.4-60a.8 & $\begin{array}{l}\text { The boys at the public bath play a prank on Nasreddin by } \\
\text { clucking and producing hen's eggs out of their bottoms. } \\
\text { Nasreddin starts crowing and molests the boys. [explicit] }\end{array}$ & Yes \\
\hline 35 & 60a.8-60b.4 & $\begin{array}{l}\text { Nasreddin and his wife decide to play mum. The wife goes } \\
\text { out to the neighbors, a thief breaks into their house. To win } \\
\text { the game Nasreddin keeps silent. The wife comes back home } \\
\text { and lets out a scream seeing everything gone. Nasreddin } \\
\text { revels in the fact that he won the game. }\end{array}$ & Yes \\
\hline 36 & 60b.5-60b.11 & $\begin{array}{l}\text { Nasreddin is having a conversation with a man visiting from } \\
\text { another town. He burps. Instead of apologizing, he says that } \\
\text { it is customary in their town. Nasreddin, in turn, farts, claim- } \\
\text { ing that it is the custom of their town. }\end{array}$ & Yes \\
\hline 37 & 61a.1-61a.5 & $\begin{array}{l}\text { Nasreddin eats two handfuls of salt every day. The towns- } \\
\text { people, fearing for his health, tell him that eating too much } \\
\text { salt leads to stupidity. He says that he does it on purpose to } \\
\text { be closer to his congregation. }\end{array}$ & Yes \\
\hline
\end{tabular}




\begin{tabular}{|c|c|c|c|}
\hline 38 & 61a.5-61a.8 & $\begin{array}{l}\text { The children of the town want to play a prank by stealing } \\
\text { Nasreddin's shoes. Having an inkling of their intention, he } \\
\text { never leaves his shoes behind, even when he climbs a tree. }\end{array}$ & Yes \\
\hline 39 & 61a.9-62a.2 & $\begin{array}{l}\text { A man climbs up a tree, but he cannot get back down. They } \\
\text { ask Nasreddin what to do. He throws the man a rope, tells } \\
\text { him to cling to it, and pulls the rope. The man falls off and } \\
\text { dies. Nasreddin says, "But the other day there was a man in } \\
\text { the well and this is exactly how they rescued him. I do not } \\
\text { understand!" }\end{array}$ & Yes \\
\hline 40 & 62a.2-62a.7 & $\begin{array}{l}\text { A man comes to Nasreddin and says, "My eye hurts. What } \\
\text { shall I do?" Nasreddin says "You should have it taken out. } \\
\text { The other day my tooth was hurting, I did so and I was } \\
\text { cured." }\end{array}$ & Yes \\
\hline 41 & 62a.7-63a.2 & $\begin{array}{l}\text { There is a heavy stone that nobody dared carry in Nasred- } \\
\text { din's town. He offers to remove it. The townspeople cheer } \\
\text { and gather to watch the spectacle. He says, "Now please put } \\
\text { it on my back so I can carry it off." }\end{array}$ & Yes \\
\hline 42 & 63a.2-64a.4 & $\begin{array}{l}\text { Nasreddin starts pulling carrots from someone else's field. } \\
\text { The owner comes and asks what he is doing. He says the } \\
\text { wind blew him to this field and he grabbed onto the carrots } \\
\text { not to be carried further. The farmer asks who put the carrots } \\
\text { in his sack. Nasreddin replies, he was just asking the same } \\
\text { question of himself. }\end{array}$ & Yes \\
\hline 43 & 64a.4-65a.4 & $\begin{array}{l}\text { Nasreddin's donkey goes missing. He finds a donkey in } \\
\text { another man's stable. He claims that the donkey is his. They } \\
\text { are brought before a judge. The judge asks if Nasreddin's } \\
\text { donkey had a distinguishing feature. Nasreddin says it can } \\
\text { read. He produces a book he laced with barley between the } \\
\text { leaves and the donkey pages through enthusiastically. }\end{array}$ & Yes \\
\hline 44 & 65a.5-65a.10 & $\begin{array}{l}\text { A man holding an egg in his palm offers to make an } \\
\text { omelette for Nasreddin if he can answer the riddle that goes } \\
\text { "Sunny on the inside, white on the outside." Nasreddin says, } \\
\text { "I know what it is, you took a white turnip, hollowed it out, } \\
\text { and stuffed it with carrot!" }\end{array}$ & Yes \\
\hline 45 & 65a.10-65b.1 & $\begin{array}{l}\text { The townsmen wonder what happens to the moon at the end } \\
\text { of the month as the new moon appears. Nasreddin says they } \\
\text { cut it into pieces to make stars. }\end{array}$ & Yes \\
\hline 46 & $65 b .2-65 b .6$ & $\begin{array}{l}\text { Nasreddin has a pest problem at home. He burns down his } \\
\text { house to exterminate the fleas. He dances in joy saying that } \\
\text { he won the war against the crawlies. }\end{array}$ & Yes \\
\hline 47 & $65 b .6-66 b .2$ & $\begin{array}{l}\text { Nasreddin's donkey is very obstinate and will not move. } \\
\text { A man suggests that he smear its behind with sal ammo- } \\
\text { niac. The smart from the ointment makes the donkey sprint } \\
\text { towards Nasreddin's house. Not being able to catch it, } \\
\text { Nasreddin decides to put some ointment on his behind. }\end{array}$ & Yes \\
\hline 48 & 66b.3-66b.10 & $\begin{array}{l}\text { Nasreddin loses his donkey, a neighbor brings it back. He } \\
\text { tells his son to water and feed the animal while he is looking } \\
\text { for his lost donkey. }\end{array}$ & Yes \\
\hline
\end{tabular}




\begin{tabular}{|c|c|c|c|}
\hline 49 & 66b.11-67a.6 & $\begin{array}{l}\text { An Arab guest arrives at Nasreddin's table. During the meal } \\
\text { Nasreddin passes wind several times. His page boy says, } \\
\text { "Hoca, do you not think we have offended our guest?" } \\
\text { Nasreddin says, "Arabs will not know how the Turks fart, so } \\
\text { we are in the clear." }\end{array}$ & Yes \\
\hline 50 & $67 a .6-67 a .8$ & $\begin{array}{l}\text { The townspeople ask Nasreddin which musical instrument } \\
\text { he likes best. He says that he is partial to pots and pans. }\end{array}$ & Yes \\
\hline 51 & $67 a .9-67 b .5$ & $\begin{array}{l}\text { Nasreddin offers to carry a group of blind men across the } \\
\text { stream for one coin each. He mishandles the raft and one of } \\
\text { the blind men falls into the stream. Nasreddin does not even } \\
\text { attempt to rescue the man, but says, "It's OK. I'll simply } \\
\text { charge you one coin less." }\end{array}$ & Yes \\
\hline 52 & 67b.5-67b.10 & $\begin{array}{l}\text { Nasreddin comes across a group of beautiful women. He } \\
\text { flirts with them, but they mock the old man saying even his } \\
\text { beard is grey. He says, "A grey dog is still a dog." }\end{array}$ & Yes \\
\hline 53 & 67b.11-69a.5 & $\begin{array}{l}\text { Nasreddin tries to sell a small rug as a door-to-door sales- } \\
\text { man. He engages in sexual transactions with the women at } \\
\text { each address. [explicit] }\end{array}$ & $\begin{array}{l}\text { He } \\
\text { abandons } \\
\text { translation } \\
\text { halfway } \\
\text { through. }\end{array}$ \\
\hline 54 & 69a.6-69a.10 & $\begin{array}{l}\text { They offer Nasreddin nine aspers in his dream. He says, } \\
\text { "Make it ten and I will take it." Then, he wakes up and } \\
\text { pleads, "OK, nine aspers but please give it in cash now." }\end{array}$ & Yes \\
\hline 55 & 69a.10-69b.5 & Nasreddin tries to seduce his sibling. [explicit] & Yes \\
\hline 56 & $69 \mathrm{~b} .5-69 \mathrm{~b} .8$ & [The same story as Tale 32, with different wording.] & Yes \\
\hline 57 & 69b.8-70b.4 & $\begin{array}{l}\text { A man rescues Nasreddin from sinking into a swamp. The } \\
\text { man asks what he would give him as a reward. Nasreddin } \\
\text { says, "Nothing." The man hastily takes Nasreddin's purse, } \\
\text { takes out a few coins. Nasreddin asks, "What did you take?" } \\
\text { The man answers, "Nothing." }\end{array}$ & Yes \\
\hline 58 & 70b.4-71b.5 & $\begin{array}{l}\text { Nasreddin thinks he died because his hands and face are } \\
\text { cold. }\end{array}$ & Yes \\
\hline 59 & 71b.5-72a.1 & $\begin{array}{l}\text { A thief breaks into Nasreddin's house and puts all the valu- } \\
\text { ables into his sack. As he is leaving, he bumps into Nasred- } \\
\text { din carrying his mattress. The thief asks Nasreddin where he } \\
\text { is going. Nasreddin says, "I am moving into your place." }\end{array}$ & Yes \\
\hline 60 & 72a.1-72a.10 & $\begin{array}{l}\text { Nasreddin cuts his donkey's tail because it was smeared in } \\
\text { mud. }\end{array}$ & Yes \\
\hline 61 & 72a.10-73a.1 & $\begin{array}{l}\text { One day Nasreddin sings at the public baths. He is very } \\
\text { pleased with his voice. He runs out of the bath, climbs the } \\
\text { minaret, and calls the congregation to prayer. }\end{array}$ & Yes \\
\hline 62 & 73a.1-73a.10 & $\begin{array}{l}\text { Nasreddin falls into the enemy's hands. Their sultan orders } \\
\text { his death right away. Nasreddin rejoices saying, "I could not } \\
\text { have asked for more, an immediate death!” Not knowing } \\
\text { what to do, the sultan orders his men to release this prisoner. }\end{array}$ & Yes \\
\hline
\end{tabular}




\begin{tabular}{|l|l|l|l|}
\hline 63 & $73 a .10-74 a .6$ & $\begin{array}{l}\text { They send Nasreddin as an ambassador to Tamerlane's } \\
\text { court. Unimpressed with Hoca's manners and conduct, } \\
\text { Tamerlane asks, "Was there no one better than you in your } \\
\text { land to be sent to me?" Nasreddin replies, "Each soul gets } \\
\text { what he deserves." }\end{array}$ & Yes \\
\hline 64 & $74 a .6-74 b .3$ & $\begin{array}{l}\text { Nasreddin goes to Konya and enters a pastry shop. He takes } \\
\text { a pie and starts munching it. The shopkeeper starts beating } \\
\text { this unruly stranger with no manners. Overjoyed, Nasreddin } \\
\text { says, "Oh, what a wonderful province this Konya is, they pat } \\
\text { you in the back even before you choke on your food!" }\end{array}$ & Yes \\
\hline 65 & $74 b .3-75 a .11$ & $\begin{array}{l}\text { Nasreddin's wife boils rags in huge cauldrons. Mistaking her } \\
\text { efforts for the preparation of a big feast, Nasreddin invites } \\
\text { the whole town for dinner. Nasreddin soon figures there is } \\
\text { no food to be had and goes in hiding. }\end{array}$ & Yes \\
\hline 66 & $75 a .11-75 b .7$ & $\begin{array}{l}\text { Nasreddin sees a dog in the mosque and thinks it is the } \\
\text { muezzin. }\end{array}$ & Yes \\
\hline 67 & $75 b .7-76 a .11$ & $\begin{array}{l}\text { Nasreddin goes out of the house to the adjacent toilet. On } \\
\text { his way back he sees an intruder at the hallway. He takes his } \\
\text { bow and shoots the man. In the morning he realizes that he } \\
\text { shot his shirt that was hanging in the hallway. He says, "I } \\
\text { am lucky that I was not wearing that shirt when I shot it." }\end{array}$ & Yes \\
\hline
\end{tabular}


